Check for updates

\section{Data report: composite depth scale and splice revision for IODP Site U1488 (Expedition 363 Western Pacific Warm Pool) using XRF core scanning data and core images ${ }^{1}$}

Anna Joy Drury, ${ }^{2,3}$ Denise K. Kulhanek, ${ }^{4,5}$ Thomas Westerhold, ${ }^{2}$

Ana Christina Ravelo, ${ }^{6}$ Gregory Mountain, ${ }^{7}$ Ann Holbourn, ${ }^{5}$ Yair Rosenthal, ${ }^{7}$

Anaïs Schmitt, ${ }^{8}$ Jennifer B. Wurtzel,,${ }^{9,10}$ Jian Xu, ${ }^{11}$ Roy Wilkens, ${ }^{12}$ and Ursula Röhl ${ }^{2}$

Keywords: International Ocean Discovery Program, IODP, JOIDES Resolution, Expedition 363, Western Pacific Warm Pool, Site U1488, composite depth scale revision, composite splice revision, composite core images

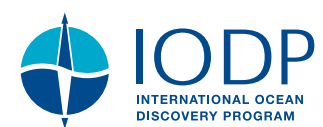

Contents

$\begin{aligned} 1 & \text { Abstract } \\ 1 & \text { Introduction } \\ 2 & \text { Methods and materials } \\ 4 & \text { Results } \\ 4 & \text { Summary } \\ 4 & \text { Acknowledgments } \\ 19 & \text { References }\end{aligned}$

\section{Abstract}

The Western Pacific Warm Pool (WPWP) is a major source of heat and moisture to the atmosphere. Small perturbations in WPWP sea-surface temperatures greatly influence local Hadley and Walker cells, thereby affecting global atmospheric circulation patterns. International Ocean Discovery Program (IODP) Expedition 363 sought to document the regional expression and driving mechanisms of WPWP climate variability during the Neogene on millennial, orbital, and geological timescales. Located in the heart of the WPWP, IODP Site U1488 $\left(02^{\circ} 02.59 \mathrm{~N}, 141^{\circ} 45.29^{\prime} \mathrm{E}\right)$ was drilled in $2604 \mathrm{~m}$ water depth on the southern part of the Eauripik Rise in the Caroline Basin. At Site U1488, a continuous shipboard composite stratigraphic section from 0 to $\sim 331 \mathrm{~m}$ core composite depth below seafloor (CCSF) was compiled using high-resolution shipboard physical property data from three holes. This section comprises upper Miocene to recent foraminifer-rich nannofossil ooze and foraminifer-nannofossil ooze, making Site U1488 ideally suited to reconstruct the paleoceanographic history of the central WPWP region. However, the high carbonate content ( $>90 \%$ below $\sim 180 \mathrm{~m}$ CCSF) of Site U1488 sediments means that the physical property data sets commonly used for splice construction (gamma ray attenuation bulk density, magnetic susceptibility, and natural gamma radiation) were too low amplitude to provide robust constraints on splice tie points below $120 \mathrm{~m}$ CCSF. As a result, $P$-wave data, which are relatively untested as a correlation tool, became critical for correlating between holes. Here, we verify and extend the Site U1488 shipboard composite splice using high-resolution $(2 \mathrm{~cm}) \mathrm{X}$-ray fluorescence $\mathrm{Ba} / \mathrm{Sr}$ core scanning data combined with composite linescan images. Overall, using these data at Site U1488 resulted in revised core offsets that differ by up to $0.84 \mathrm{~m}$ relative to the shipboard core offsets and a composite depth scale down to $329.33 \mathrm{~m}$ revised CCSF. The revised splice will allow optimization of postexpedition research and ensure that high-resolution studies of Site U1488 are conducted on a continuous stratigraphic section.

\section{Introduction}

The Western Pacific Warm Pool (WPWP) is the largest reservoir of oceanic heat on Earth and as a result plays a pivotal role in oceanic and atmospheric heat and transport processes (Rosenthal et al., 2018a). Forming part of the larger Indo-Pacific Warm Pool,

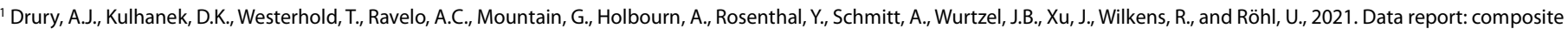
depth scale and splice revision for IODP Site U1488 (Expedition 363 Western Pacific Warm Pool) using XRF core scanning data and core images. In Rosenthal, Y., Holbourn, A.E., Kulhanek, D.K., and the Expedition 363 Scientists, Western Pacific Warm Pool. Proceedings of the International Ocean Discovery Program, 363: College Station, TX (International Ocean Discovery Program). https://doi.org/10.14379/iodp.proc.363.205.2021

2 MARUM - Center for Marine Environmental Sciences, University of Bremen, Leobener Strasse, DE-28359 Bremen, Germany.

${ }^{3}$ Department of Earth Sciences, University College London, Gower Street, London WC1E 6BT, United Kingdom. Correspondence author: a.j.drury@ucl.ac.uk

${ }^{4}$ International Ocean Discovery Program, Texas A\&M University, 1000 Discovery Drive, College Station TX 77845, USA.

${ }^{5}$ Institute of Geosciences, Christian-Albrechts-Universität zu Kiel, Ludewig-Meysnstresse 14, 24118 Kiel, Germany.

${ }^{6}$ Ocean Sciences Department, University of California, Santa Cruz, 1156 High Street, Santa Cruz CA 95064, USA.

${ }^{7}$ Department of Earth and Planetary Sciences, Rutgers University, 610 Taylor Road, Piscataway NJ 08854, USA.

${ }^{8}$ Faculty of Science and Technology, Université de Nantes, 2 rue de la Houssiniére, 44322 Nantes, France.

${ }^{9}$ Research School of Earth Sciences, The Australian National University, Building 142 Mills Road, Acton ACT 2601, Australia.

${ }^{10}$ Now at New South Wales Department of Primary Industries, Orange Agricultural Institute, 1447 Forest Road, Orange NSW 2800 , Australia.

${ }^{11}$ Department of Geology, Northwest University, 229 North Taibai Road, Xi'an Shaanxi 710069, China.

${ }^{12}$ School of Ocean and Earth Science and Technology (SOEST), University of Hawaii at Manoa, 2525 Correa Road, HIG 153, Honolulu HI 96822, USA.

MS 363-205: Received 5 May 2020 . Accepted 28 June 2021 • Published 29 October 2021

This work is distributed under the Creative Commons Attribution 4.0 International (CC BY 4.0) license. (cc))BY
} 
the WPWP is a major source of heat and moisture to the atmosphere. Small perturbations in regional sea-surface temperatures (SSTs) greatly affect the local Hadley and Walker cells and perturb global atmospheric circulation patterns, thereby significantly affecting regional and global hydrological cycles (Rosenthal et al., 2018a). Prior to Expedition 363, expanded and continuous sedimentary archives documenting WPWP Neogene history were scarce. A key objective of International Ocean Discovery Program (IODP) Expedition 363 (6 October-8 December 2016) was recovert of continuous sedimentary archives to document the regional expression and driving mechanisms of WPWP climate variability throughout the Neogene on millennial, orbital, and geological timescales.

Three holes at IODP Site U1488 $\left(02^{\circ} 02.59\right.$ N, $141^{\circ} 45.29$ E; Figure F1) were drilled in $2604 \mathrm{~m}$ water depth on the southern part of the Eauripik Rise in the Caroline Basin. Because of its location in the heart of the WPWP, Site U1488 is ideally suited to reconstruct the Neogene paleoceanographic history of the central WPWP region (Rosenthal et al., 2018c). Three holes were cored to a maximum depth of $\sim 315 \mathrm{~m}$ core depth below seafloor, method A (CSFA; hereafter referred to as meters below seafloor [mbsf]), comprising upper Miocene to recent foraminifer-rich nannofossil ooze and foraminifer-nannofossil ooze. Shipboard studies show very good to good preservation of benthic and planktonic foraminifers throughout most of the sequence, and because the site remained above the calcite compensation depth throughout its history, dissolution effects on planktonic foraminifers are minimal (Rosenthal et al., 2018c). Based on shipboard nannofossil and planktonic foraminiferal biostratigraphic and paleomagnetic datums, sedimentation rates were $\sim 2 \mathrm{~cm} / \mathrm{ky}$ in the Pleistocene and $\sim 4 \mathrm{~cm} / \mathrm{ky}$ throughout the late Miocene and Pliocene. During the expedition, high-resolution shipboard physical property data were used to construct a continuous shipboard composite depth scale and stratigraphic splice from 0 to $\sim 331 \mathrm{~m}$ core composite depth below seafloor (CCSF), which spanned from recent to $\sim 9.4$ Ma based on shipboard biostratigraphy (Rosenthal et al., 2018c).

At Site U1488, $P$-wave velocity data, which are relatively untested as a stratigraphic correlation tool, were critical for determining the hole-specific cumulative core offsets (Figure F2) (Rosenthal et al., 2018b). This was necessary because the high carbonate content at Site U1488 (>90\% below $180 \mathrm{~m} \mathrm{CCSF}$ ) meant that the physical property data sets commonly used for splice construction (gamma ray attenuation [GRA] bulk density, magnetic susceptibility [MS], and natural gamma radiation [NGR]) had amplitude variability that was too low to provide a robust means for stratigraphic correlation between holes (Figure F2) (Rosenthal et al., 2018b; Rosenthal et al., 2018c). The shipboard composite depth scale and splice were predominantly generated using MS in the upper $\sim 65 \mathrm{~m}$ CCSF (Figure F2A). Below $65 \mathrm{~m} \mathrm{CCSF}$, the amplitude of the MS data greatly decreased, and between 65 and $\sim 120$ m CCSF the composite depth scale and splice were constructed using a combination of MS, $P$-wave velocity, and GRA bulk density data. Below $120 \mathrm{~m}$ CCSF, the amplitude of the variability in the MS data was too low to use for stratigraphic correlation, so only $P$-wave velocity and GRA bulk density data were used (Figure F2B) (Rosenthal et al., 2018c).

The stratigraphic splice for Site U1488 must be robust to facilitate postexpedition research, which includes the generation of highresolution paleoclimatological records to contribute to the overarching objectives of Expedition 363. However, research on other high-carbonate content settings (e.g., Ocean Drilling Program [ODP] Site 982 in the North Atlantic) has shown that physical prop-
Figure F1. Location of Expedition 363 sites (white/yellow circles) and previously drilled Deep Sea Drilling Project (DSDP) Site 62 and ODP Site 806 (green circles). (Modified from Rosenthal et al., 2017.)

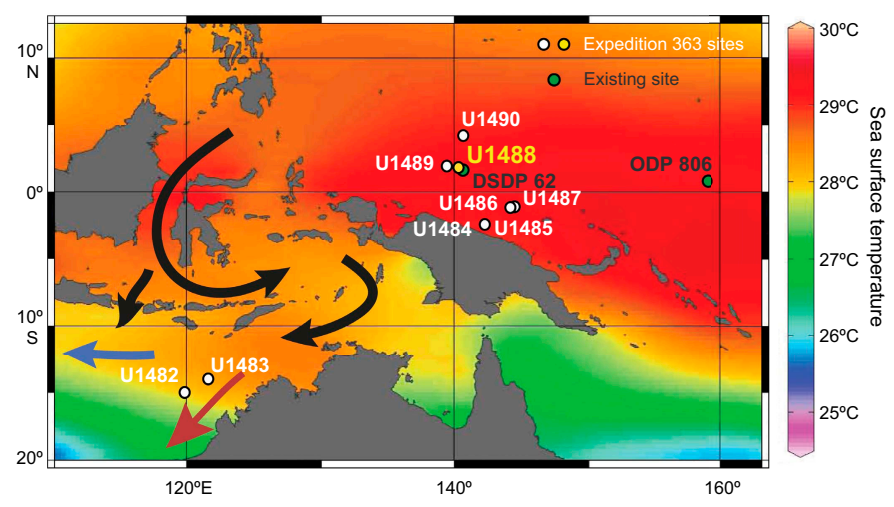

erty data can be highly unreliable for generating robust, continuous composite depth scales and stratigraphic splices (Drury et al., 2018). As such, it is crucial to verify shipboard composite depth scales and splices from high-carbonate sites such as Site U1488.

Here, we present linescan core images and high-resolution (2 $\mathrm{cm}) \mathrm{Ba} / \mathrm{Sr}$ X-ray fluorescence (XRF) core scanning data for Site U1488. We combine these two data sets with the available shipboard physical property data to verify and revise the shipboard composite depth scale and splice for Site U1488.

\section{Methods and materials XRF core scanning data}

XRF core scanner $\mathrm{Ba}$ and $\mathrm{Sr}$ data were collected every $2 \mathrm{~cm}$ downcore over a $1.2 \mathrm{~cm}^{2}$ area with a downcore slit size of $10 \mathrm{~mm}$ and a cross-core slit size of $12 \mathrm{~mm}(50 \mathrm{kV} ; 0.5 \mathrm{~mA} ; 7 \mathrm{~s}$ count time) from the split core surface of Site U1488 archive halves with the XRF Core Scanner III (AVAATECH Serial No. 12) at MARUM (the Center for Marine Environmental Sciences), University of Bremen (Germany). Where needed, the split core surface of the archive half was lightly scraped with a glass slide to achieve a flat surface suitable for XRF core scanning. The split core surface was then covered with a $4 \mu \mathrm{m}$ thick SPEXCerti Prep Ultralene1 foil to avoid contamination of the XRF measurement unit and desiccation of the sediment. The data reported here utilize the SGX Sensortech Silicon Drift Detector (Model SiriusSD D65133Be-INF with $133 \mathrm{eV}$ X-ray resolution), the Topaz-X High-Resolution Digital MCA, and an Oxford Instruments 100W Neptune X-Ray tube with rhodium (Rh) target material. The raw X-ray data spectra were processed using the Iterative Least Square software (WIN AXIL) package from Canberra Eurisys.

\section{Linescan core and spliced images}

To assist with composite depth scale and splice verification, core images for Site U1488 were compiled using Code for Ocean Drilling Data (CODD; https://www.codd-home.net) (Wilkens et al., 2017) from the digital linescan images taken during the expedition. For each hole, cropped linescan section images were downloaded from the IODP laboratory information management system (LIMS) database (https://web.iodp.tamu.edu/LORE) while on board the R/V JOIDES Resolution. Images from Sections 363-U1488C-3H-2 through $7 \mathrm{H}-\mathrm{CC}$ and $14 \mathrm{H}-5$ through $17 \mathrm{H}-\mathrm{CC}$ were slightly lightened because the original linescan images from these sections were obvi- 
Figure F2. Shipboard magnetic susceptibility (MS), shipboard $P$-wave, and new X-ray fluorescence (XRF) Ba/Sr data, Holes U1488A-U1488C. A. Shipboard MS was essential for correlation, which is confirmed by shipboard $P$-wave and XRF Ba/Sr data. B. Shipboard MS can no longer be used for correlation, but it is clear that the variability in the $P$-wave data can mostly be used to correlate between holes, which is confirmed by the XRF Ba/Sr data.
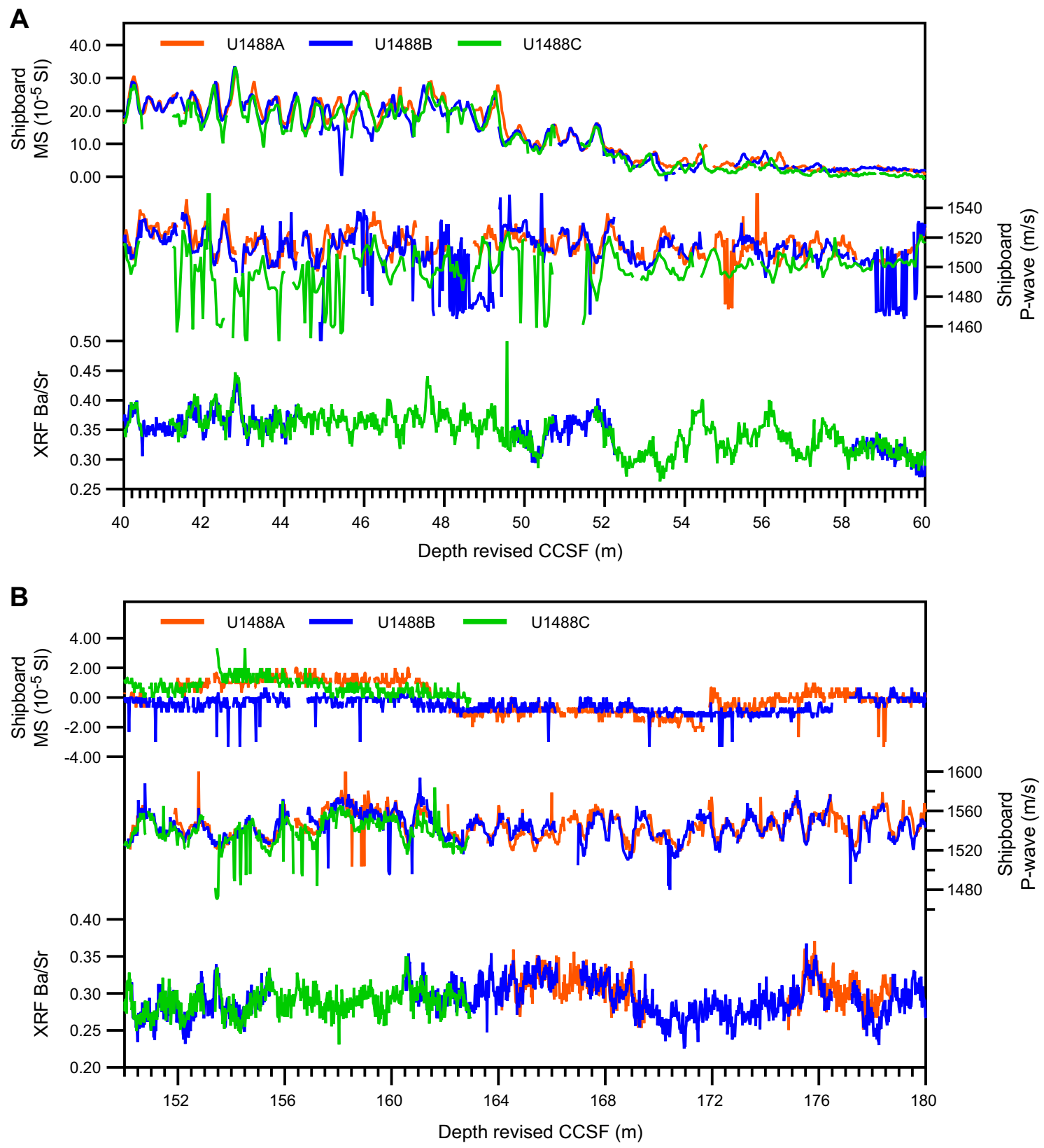

ously artificially darker than the actual sediments, as well as the preceding and succeeding section images. The corrected section-half images were then compiled into entire core images and scaled to the CCSF depth scale using the Includes_Core_Image_Assembly functions within CODD. A complete image of the entire stratigraphic splice was also compiled. All images compiled here are available on the PANGAEA database (https://www.pangaea.de).

\section{Composite depth scale and stratigraphic splice revision}

The core images and $\mathrm{Ba} / \mathrm{Sr}$ data were combined with the shipboard physical property data to verify and, where needed, revise the shipboard composite depth scale and splice for Site U1488. The con- struction of a revised composite depth scale and splice generally followed the original shipboard methodology (Rosenthal et al., 2018b; Rosenthal et al., 2018c), which builds on the basic strategy first applied during ODP Leg 138 (Ruddiman et al., 1987; Hagelberg et al., 1992, 1995). During the expedition, Hole U1488C was used as the "backbone" of the upper section of the splice and Hole U1488B was used to cover core gaps. For the lower section, Hole U1488B was the backbone and Hole U1488A was used to cover core gaps (Rosenthal et al., 2018c). This strategy enables the use of off-splice core intervals to make a secondary near-continuous off-splice succession suitable for low-resolution sampling that avoids the more heavily sampled splice (see the OFFSPLICE folder in Supplementary material; Rosenthal et al., 2018d). Where appropriate, we maintained the ship- 
board interhole relationships and tie points when revising the CCSF depth scale and splice. Where the new data showed the shipboard offsets and splice required revision, we chose interhole ties and splice intervals that avoided the top and bottom $\sim 50 \mathrm{~cm}$ and disturbed intervals of a core. We chose splice intervals from cores that best represented the stratigraphic characteristics of the section in question.

Here, we report depths on the core depth below seafloor, method A (CCSF-A) depth scale as meters below seafloor (mbsf) in line with the terminology used in the Expedition 363 Proceedings (Rosenthal et al., 2018b). The shipboard composite depth scale "core composite depth below seafloor" is referred to as CCSF. The revised composite depth scale is referred to as "revised CCSF." The CODD Includes_SplicingRevise_Menu was used to assist with the composite verification and revision process (Wilkens et al., 2017). As with the shipboard CCSF depth scale and splice, features used for correlating between holes and creating the revised CCSF depth scale and splice are only precisely correlated between holes at the exact location of the splice and/or offset tie point. Away from these ties, the correlation of individual stratigraphic features within a core may be less accurate between holes. Studies from other sites have provided an adjusted CCSF depth scale where the off-splice intervals are adjusted or "mapped" onto the splice to ensure as accurate a correlation between holes as possible (e.g., adjusted CCSF [Wilkens et al., 2013]; CCSF-M [van Peer et al., 2017)]. This could not be done for Site U1488 because the physical property data and core images were not distinct enough to use accurately and the XRF data were not collected for all holes.

\section{Results}

\section{Revised composite depth scale}

The XRF core scanning ratio of $\mathrm{Ba} / \mathrm{Sr}$ provided a robust proxy for stratigraphic correlation between all three holes (Figure F3). The shipboard cumulative core offsets were initially rounded to the nearest centimeter. In total, the offsets for 26 cores were changed from the shipboard offsets (Table T1; Figure F3):

- Cores 363-U1488A-14H, 21H, 23H, 26H, 31H, 34F, and 35F;

- Cores 363-U1488B-2H, 8H, 10H-11H, 18H, 21H, 23H, 27H-

$28 \mathrm{H}, 30 \mathrm{H}-31 \mathrm{H}$, and $33 \mathrm{H}$; and

- Cores 363-U1488C-3H, 9H-10H, 12H-14H, and 16H.

Most changes are small, and the revised offsets generally differ $0.02-0.17 \mathrm{~m}$ relative to the shipboard offsets. A further three offsets were changed by $0.30-0.32 \mathrm{~m}$ (Cores $363-\mathrm{U} 1488 \mathrm{~A}-26 \mathrm{H}$ and $34 \mathrm{~F}-$ 35F; Figure F3K, F3N). Two of these changes were to the successive core gaps between Cores 363-U1488B-33H, 363-U1488A-34F, and 363-U1488A-35F, where the original growth factor-derived offset was increased by $30 \mathrm{~cm}$ to make it clearer that these cores are not part of a continuous succession (Table T1).

The largest changes to the shipboard offsets occurred in Cores 363-U1488C-12H (+0.74 m; Figure F3E) and 363-U1488B-27H (-0.75 $\mathrm{m}$; Figure F3K) and 363-U1488B-31H (-0.84 m; Figure F3L, F3M). Changes to offsets were applied to every core in all holes below the depth of the core that was shifted, resulting in cumulative changes of $0.03-1.59 \mathrm{~m}$ in the revised CCSF scale relative to the shipboard CCSF scale (Table T1).

All preconditioned physical property data ("cleaned" GRA, MS, $P$ wave, and NGR) for Holes U1488A, U1488B, and U1488C were revised to the updated CCSF. These data are available as supplementary tables ST1-ST12 in the DATA_HOLE folder in the Supplementary material for this data report. During the expedition, preconditioning treatments were applied to the raw records to "clean up" and aid in the interpretation of noisy or spiky data (for details, see Physical properties in the Methods chapter [Rosenthal et al., 2018b]). The preconditioned physical property data ("cleaned" GRA, MS, P-wave, and NGR) provided along the revised stratigraphic splice are available as supplementary tables ST1-ST4 in the DATA_SPLICE folder in the Supplementary material for this data report.

\section{Revised stratigraphic splice}

The revised composite depth scale results in an updated stratigraphic splice down to $329.33 \mathrm{~m}$ revised CCSF (Table T2). Appended Cores 363-U1488A-34F and 35F extend the total sedimentary succession to $339.69 \mathrm{~m}$ revised CCSF overall (Table T2). The revised composite depth scale required adjustment of 25 splice tie points. Mostly, these changes constituted small revisions to optimize the location of the splice tie point between two holes within a sedimentary cycle. In addition, the exact interval and mbsf depth of some of the shipboard ties were adjusted by up to $1 \mathrm{~cm}$ to accommodate the rounding of the shipboard offsets to the nearest centimeter prior to revision of the composite depth scale (Tables T1, T2; both also available in the TABLES folder in the Supplementary material for this data report).

The largest revision occurred around $\sim 134 \mathrm{~m}$ revised CCSF between Cores 363-U1488B-14H and 363-U1488C-14H, where a small section of Core 363-U1488A-14H was originally included in the shipboard splice. Following revision of the composite depth scale, Cores 363-U1488B-14H and 363-U1488C-14H were correlated at $134.13 \mathrm{~m}$ revised CCSF and Core 363-U1488A-14H was removed from the splice (Figure F3F). Generally, most splice ties are robust because there is excellent agreement between the XRF data, composite core photos, and physical property data among holes.

The splice tie point from Core 363-U1488A-32H to Core 363$\mathrm{U} 1488 \mathrm{~B}-33 \mathrm{H}$ at $323.20 \mathrm{~m}$ revised CCSF remains ambiguous and should be treated cautiously because the XRF data did not provide a good correlation between the cores from different holes (Figure F3M). This interhole variability could be due to increased coring disturbance at the base of both holes. This tie point cannot be better resolved with the current data. However, because this tie point is located at the base of the revised splice, the consequences for highresolution studies should be minimal.

\section{Summary}

We present a revised composite depth scale and stratigraphic splice for Site U1488, which was generated using XRF Ba/Sr core scanning data, linescan core images, and physical property data. The revised cumulative offsets differ by up to $0.84 \mathrm{~m}$ relative to the shipboard offsets. Splice tie points were adjusted where needed. Site U1488 now has a continuous and expanded revised composite depth scale down to $329.13 \mathrm{~m}$ revised CCSF. This revised splice will especially benefit postexpedition research that utilizes high-resolution studies on Site U1488 sediments and will contribute toward understanding orbitalscale climate dynamics in the central WPWP over the last $9.4 \mathrm{My}$.

\section{Acknowledgments}

We thank the Captain, crew, and shipboard science party for their contributions to the recovery and preliminary analysis of the material recovered during IODP Expedition 363. We gratefully acknowledge the kind assistance of Holger Kuhlmann, Alex Wülbers, 
Figure F3. A-N. Linescan core images and XRF Ba/Sr ratios for Holes U1488A (orange), U1488B (blue), and U1488C (green), as well as the spliced core images on the original shipboard composite depth scale and stratigraphic splice (upper panel) and on the revised composite and stratigraphic splice (lower panel). Yellow and red lines denote the top (yellow) and base (red) of intervals from a core included in the splice. Solid lines indicate where shipboard splice ties remained unchanged, and dashed lines indicate where changes were made (Table T2). (Continued on next thirteen pages.)

A Shipboard

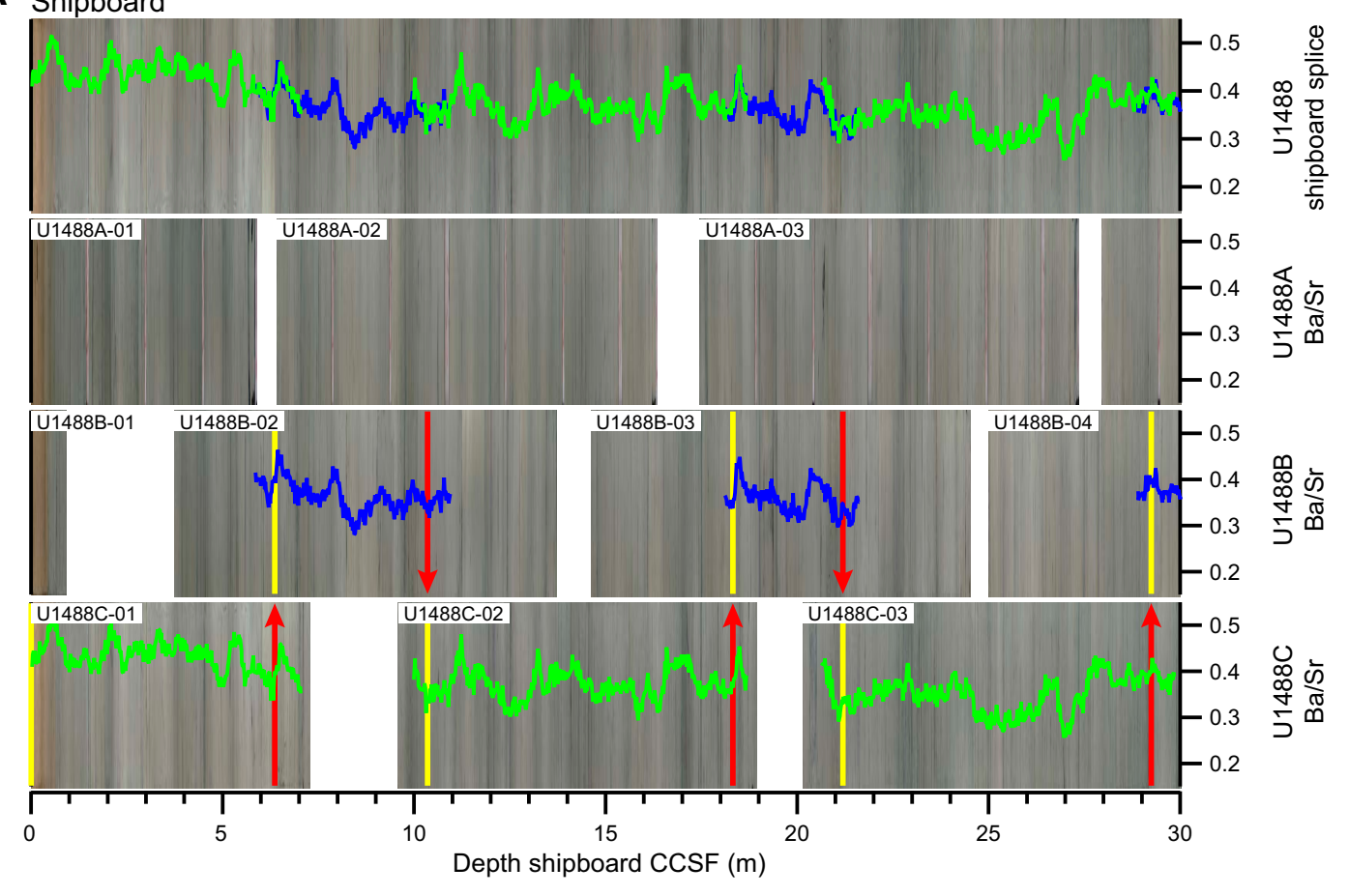

Revised (this study)

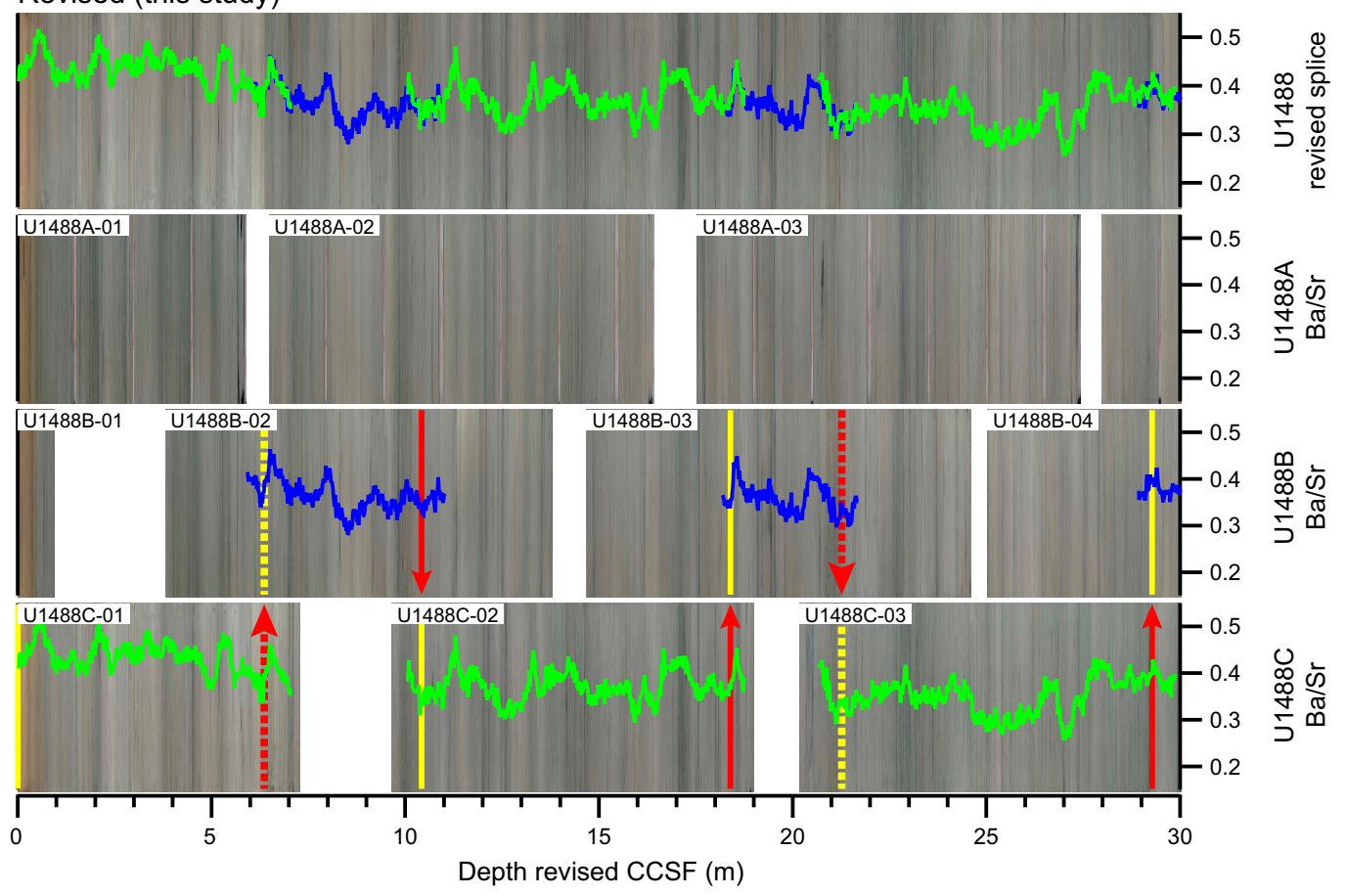


Figure F3 (continued).

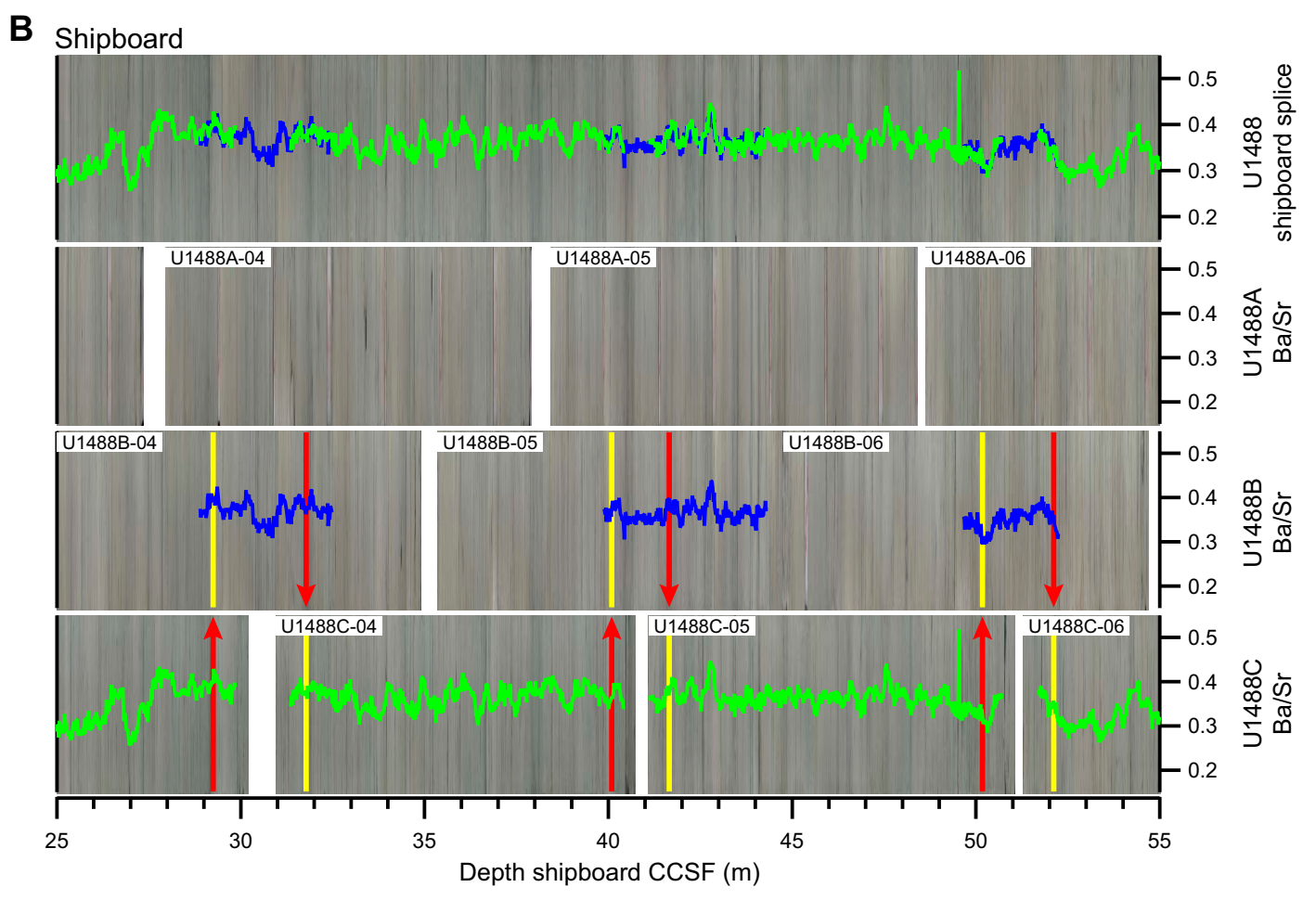

Revised (this study)

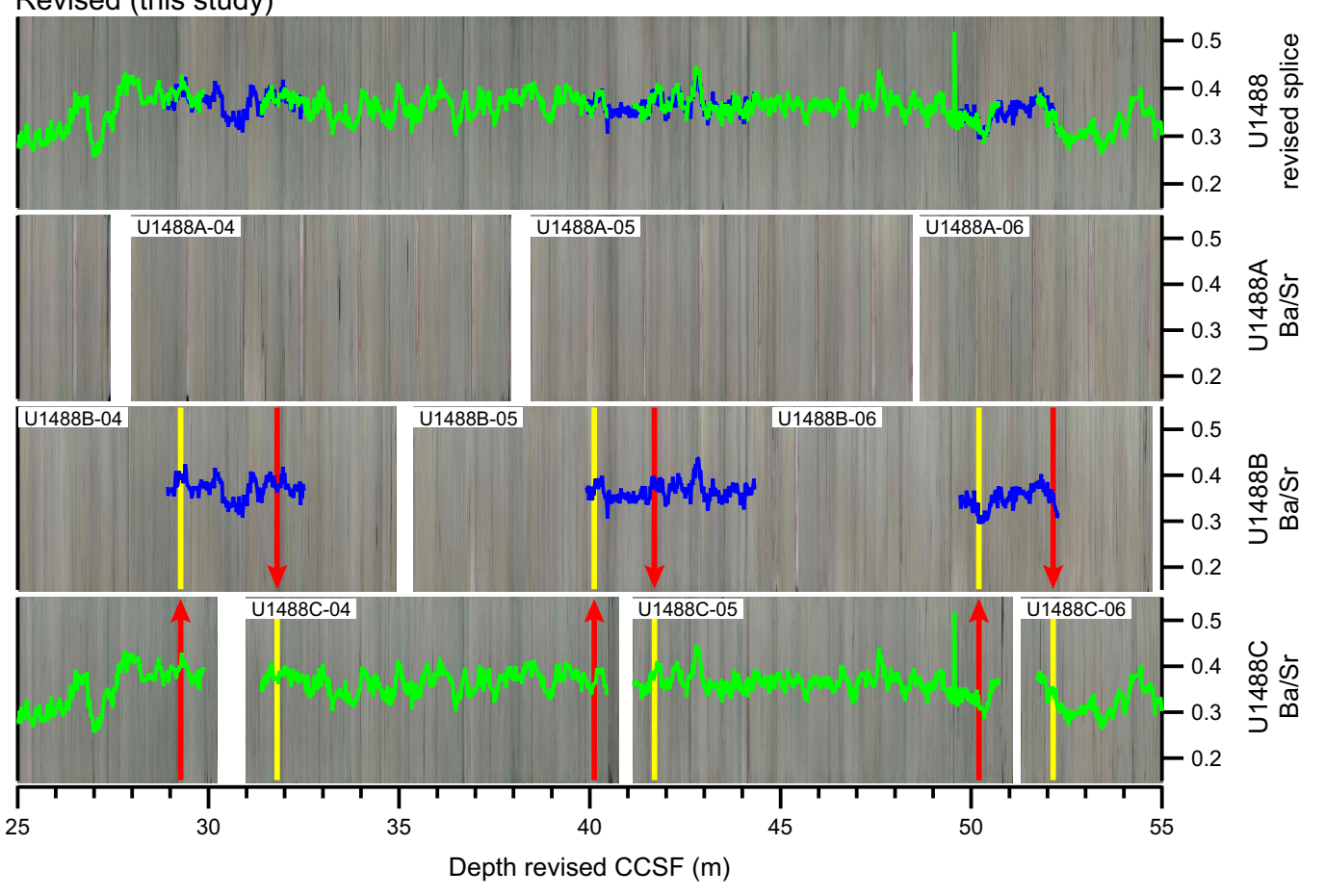


Figure F3 (continued).

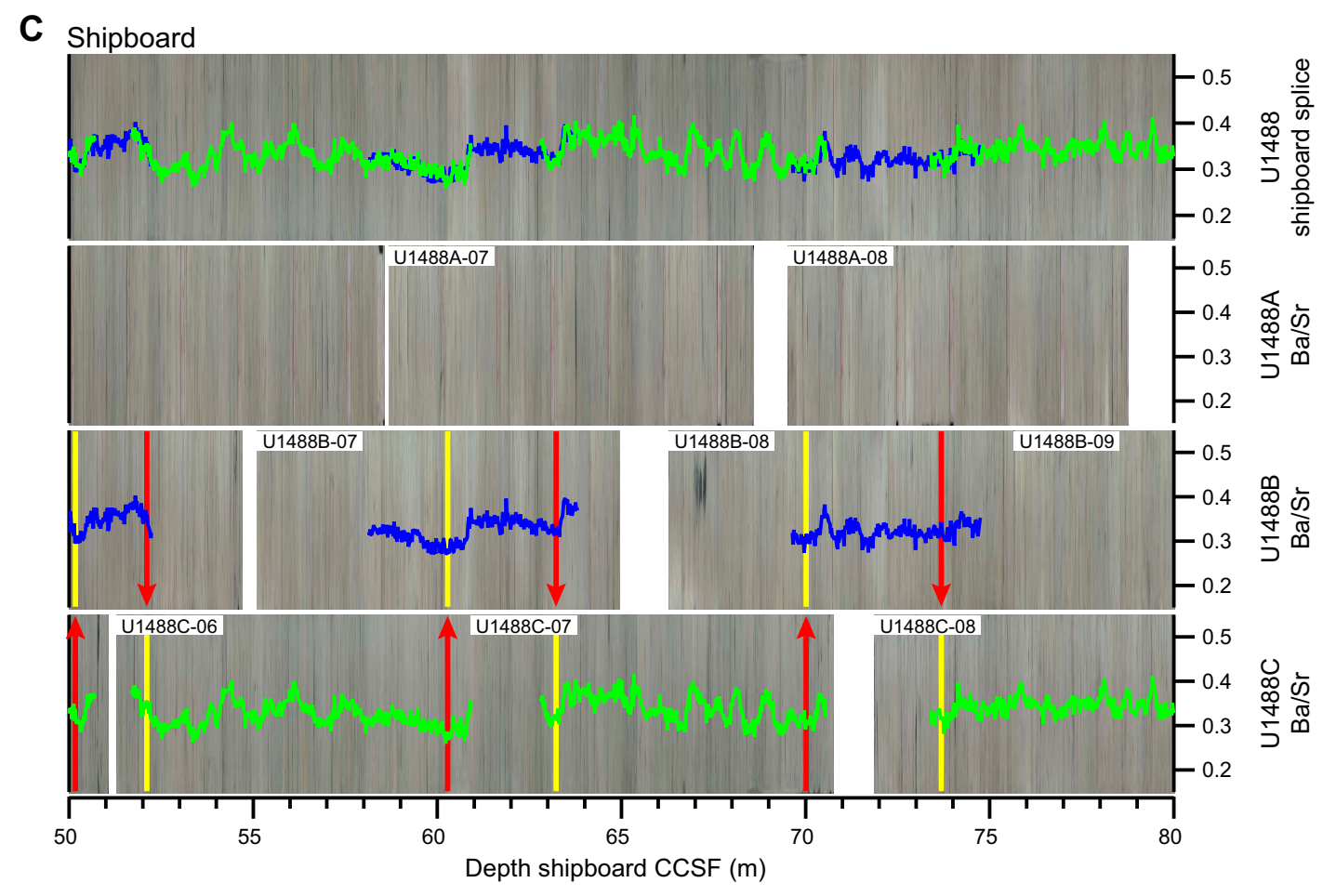

Revised (this study)

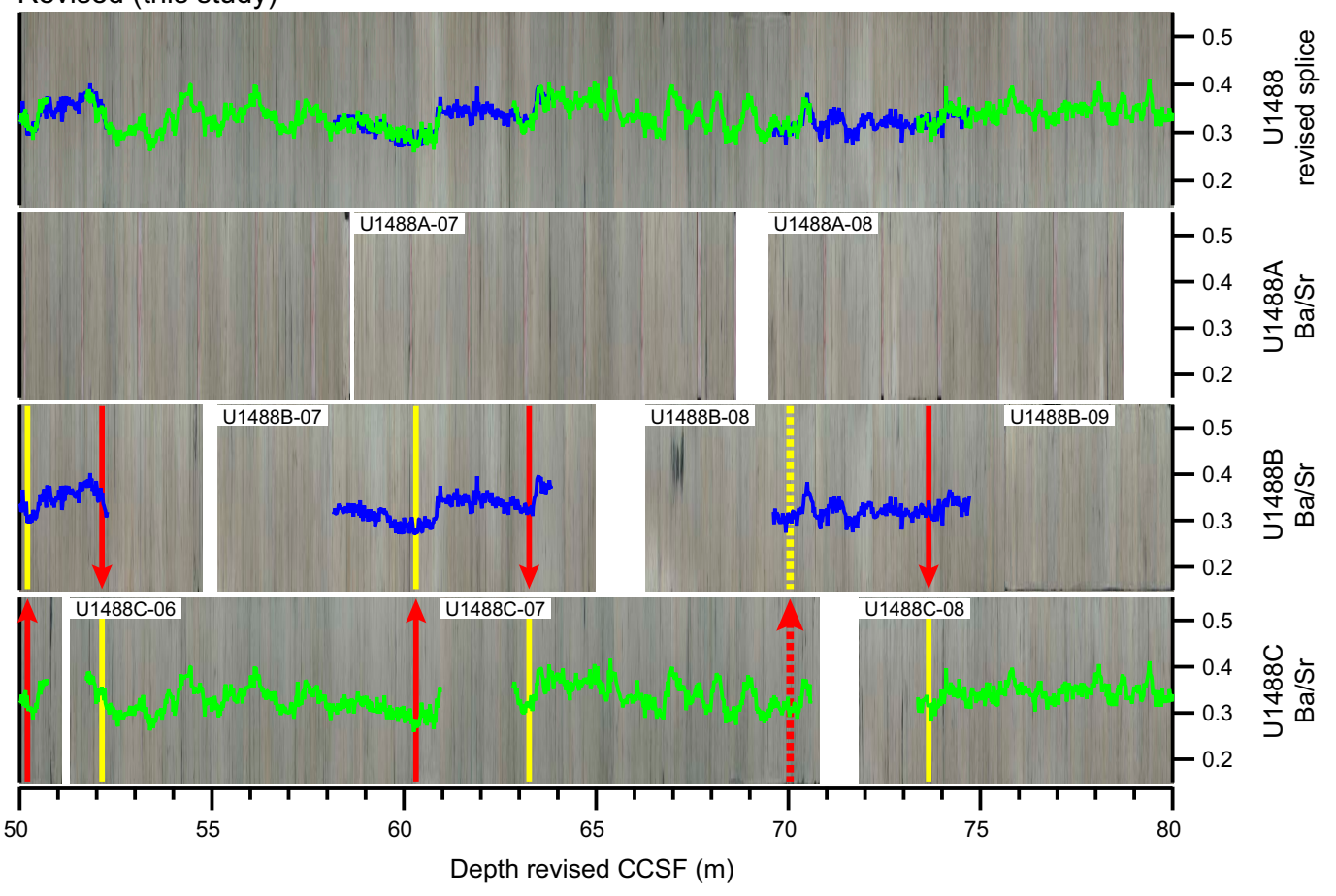


Figure F3 (continued).

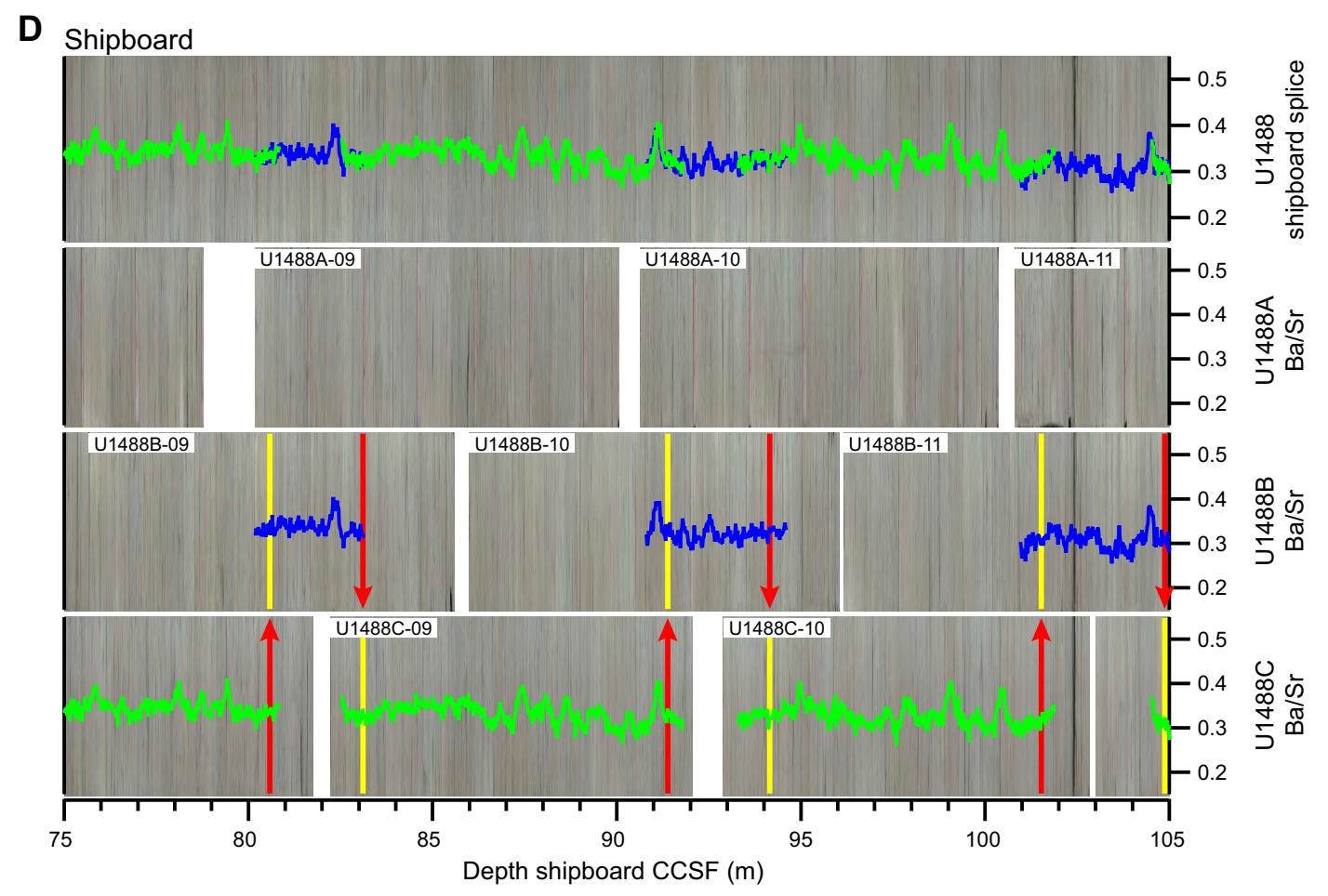

Revised (this study)

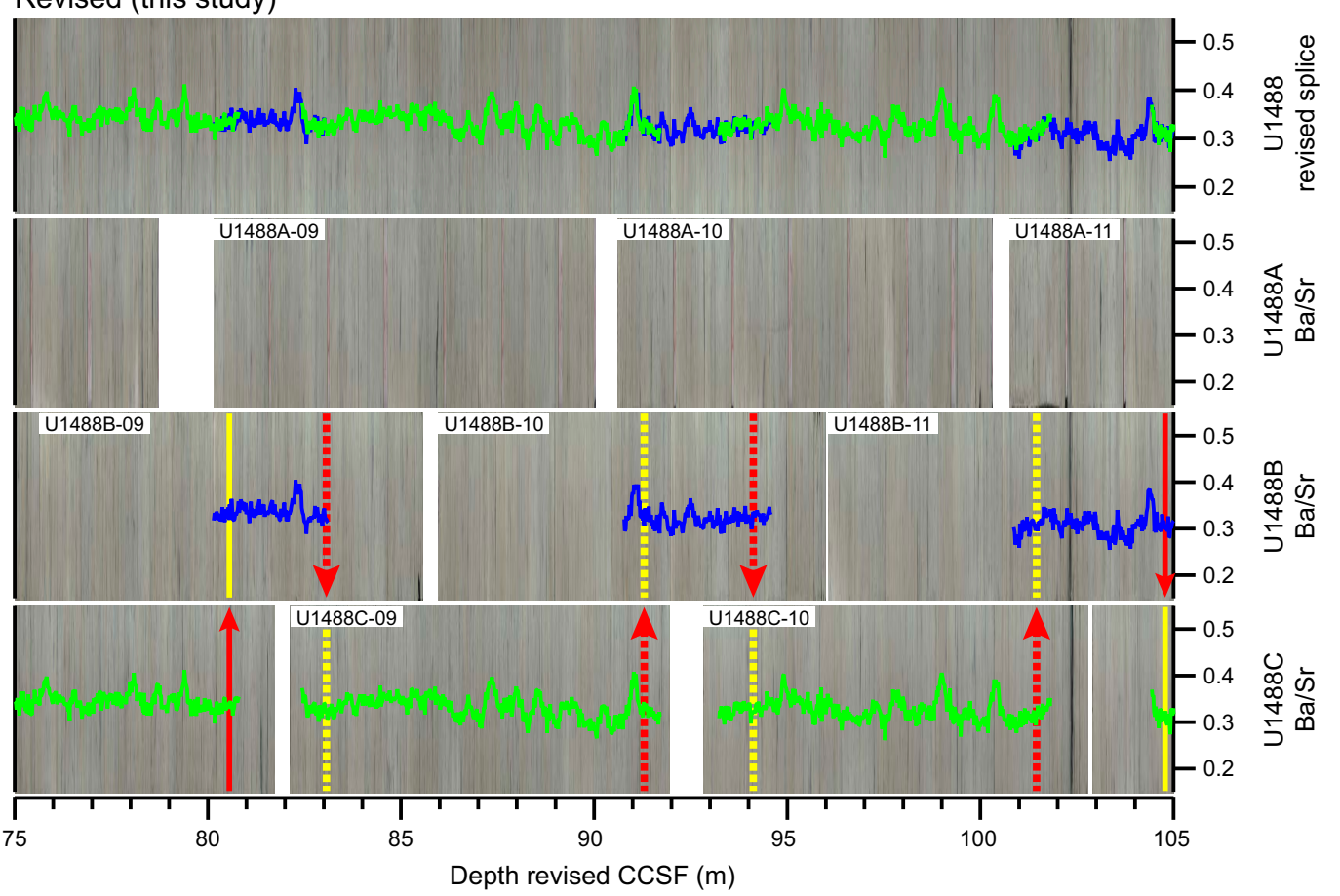


Figure F3 (continued).

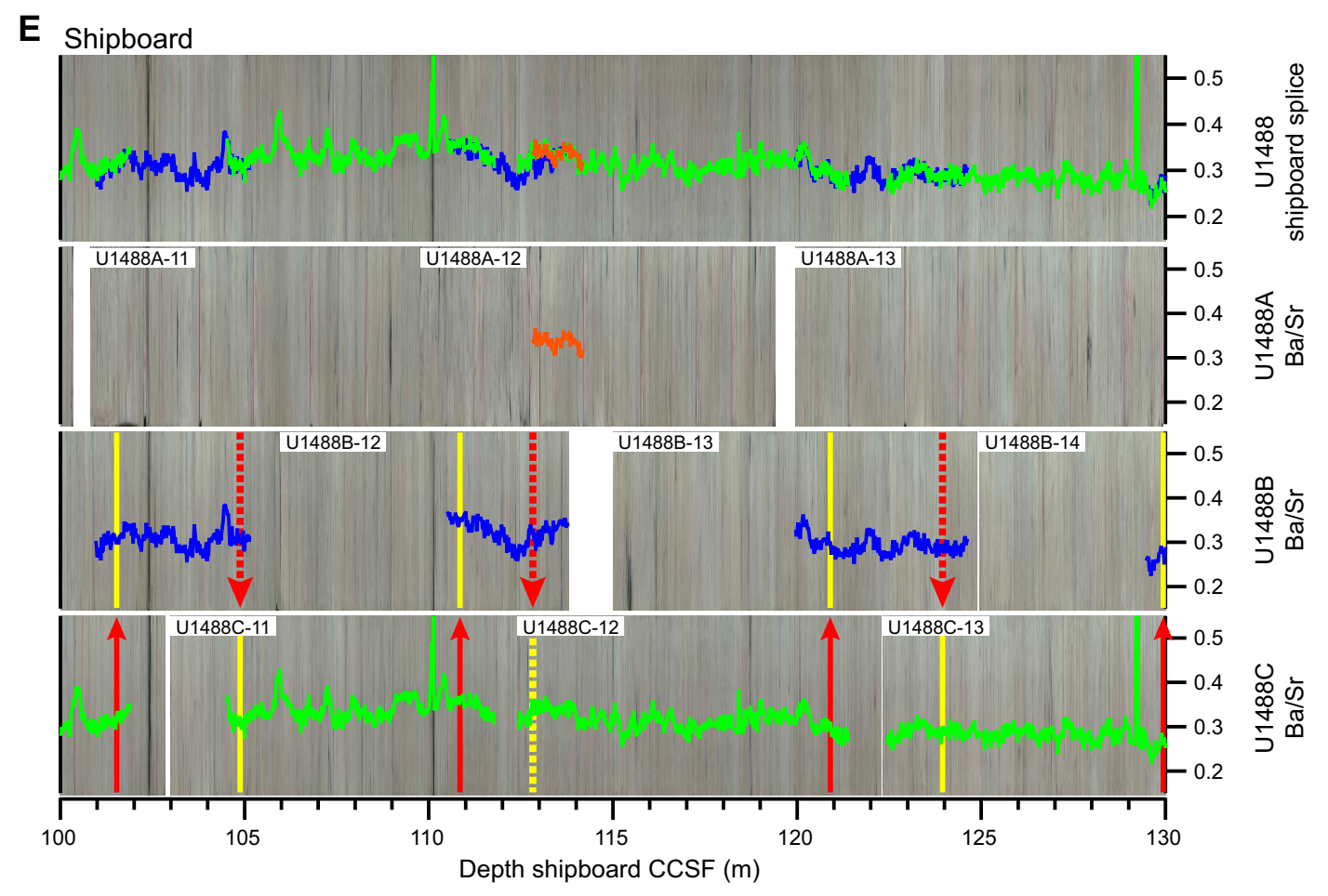

Revised (this study)

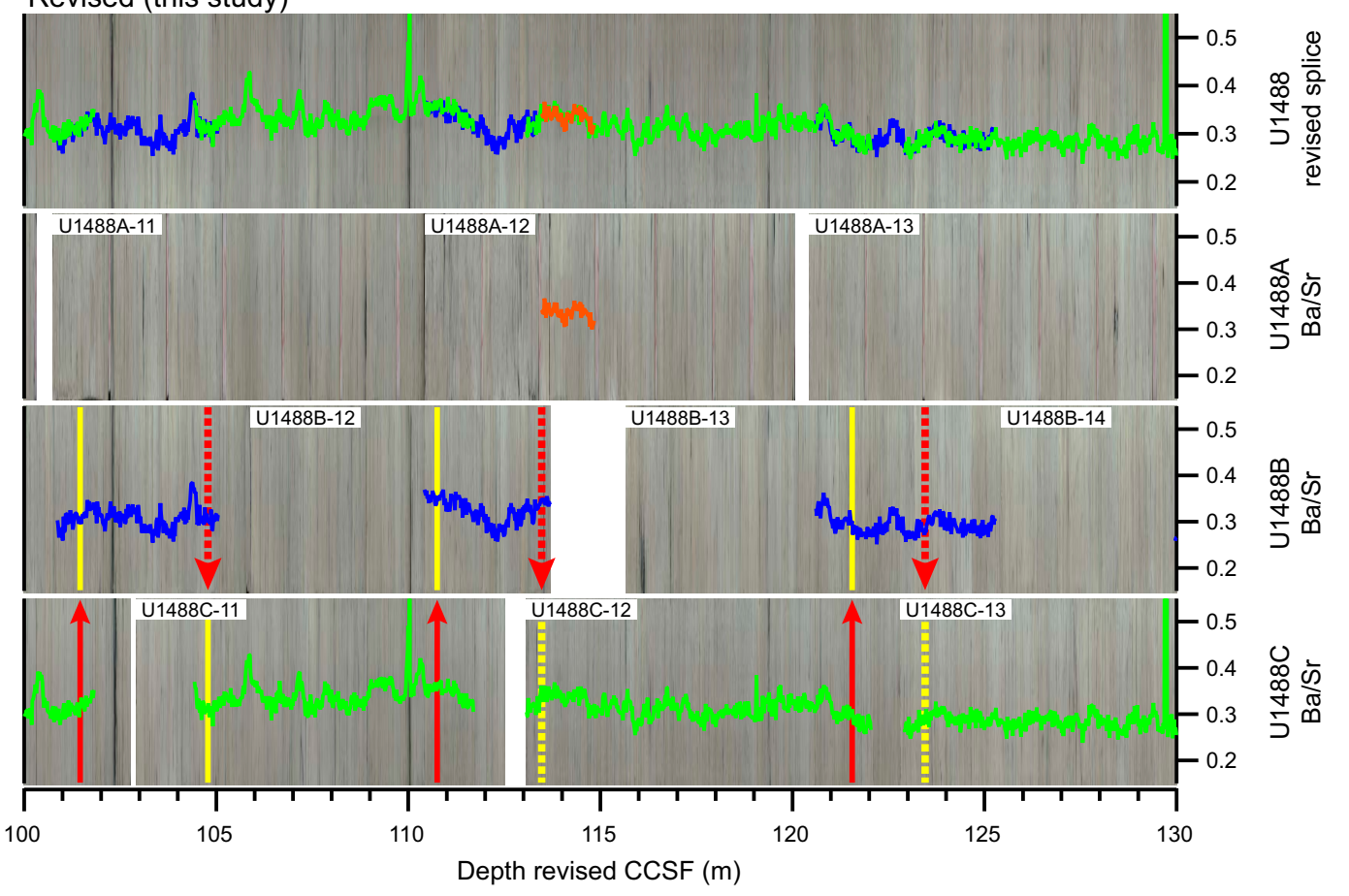


Figure F3 (continued).
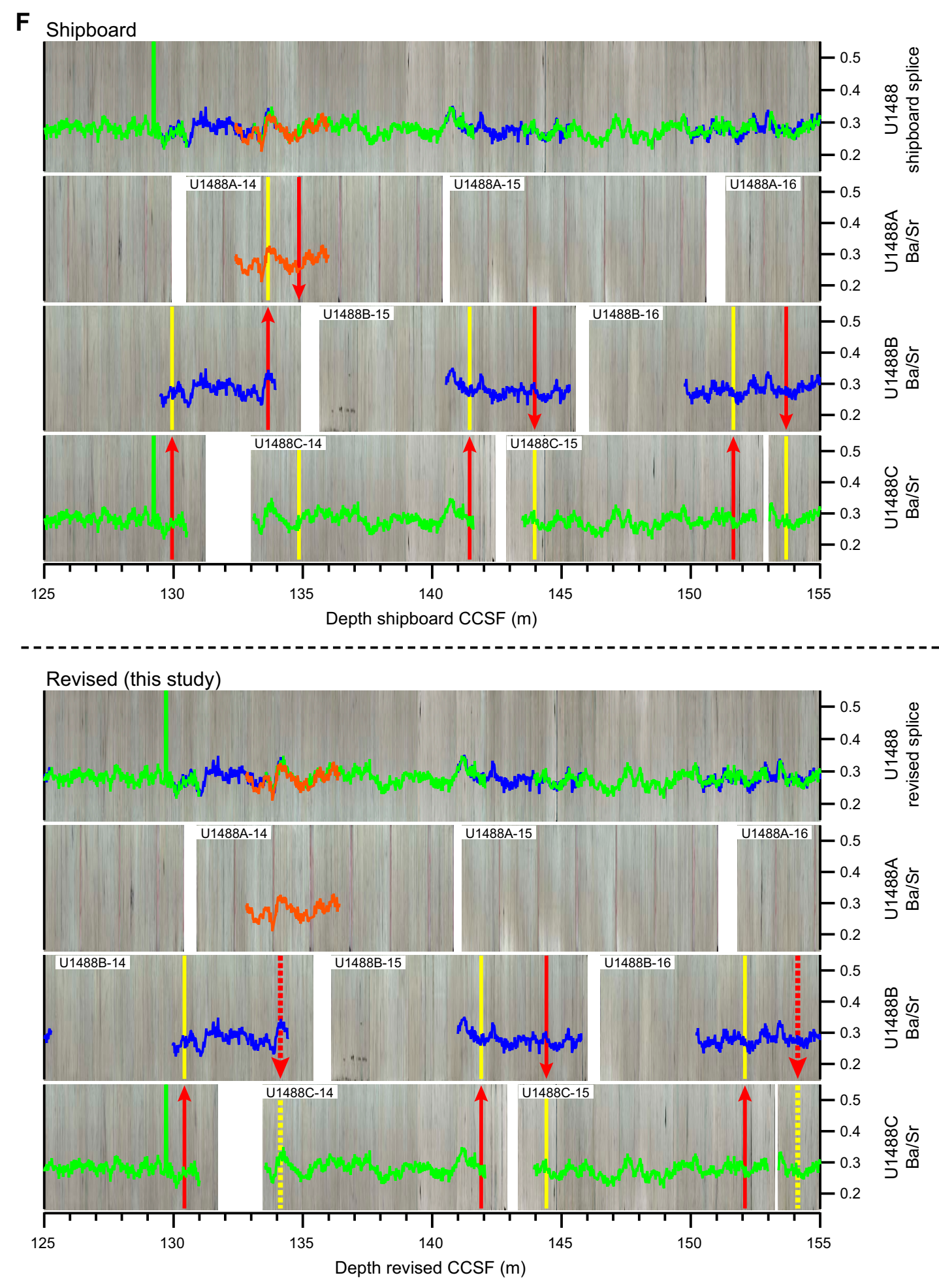
Figure F3 (continued).

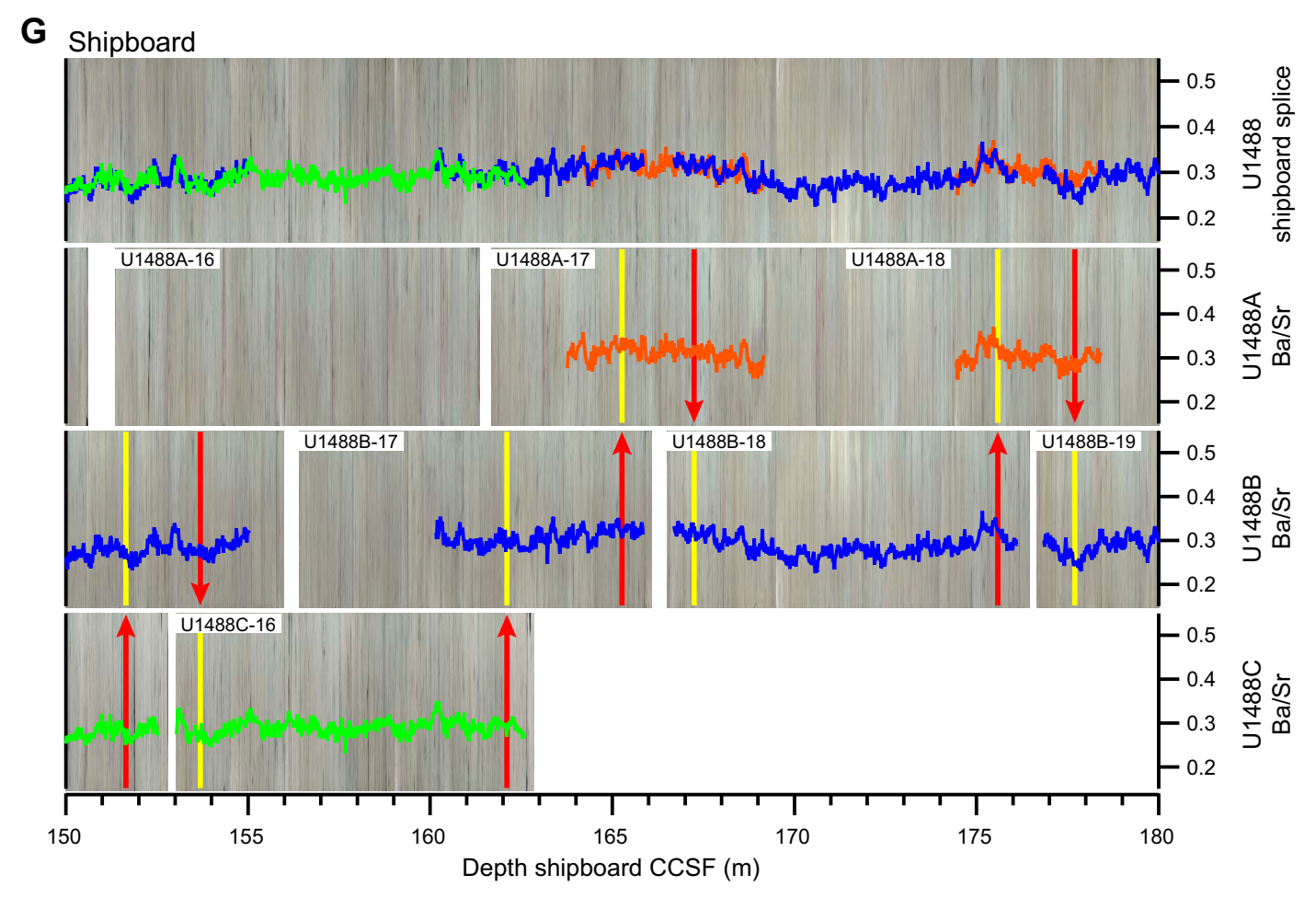

Revised (this study)

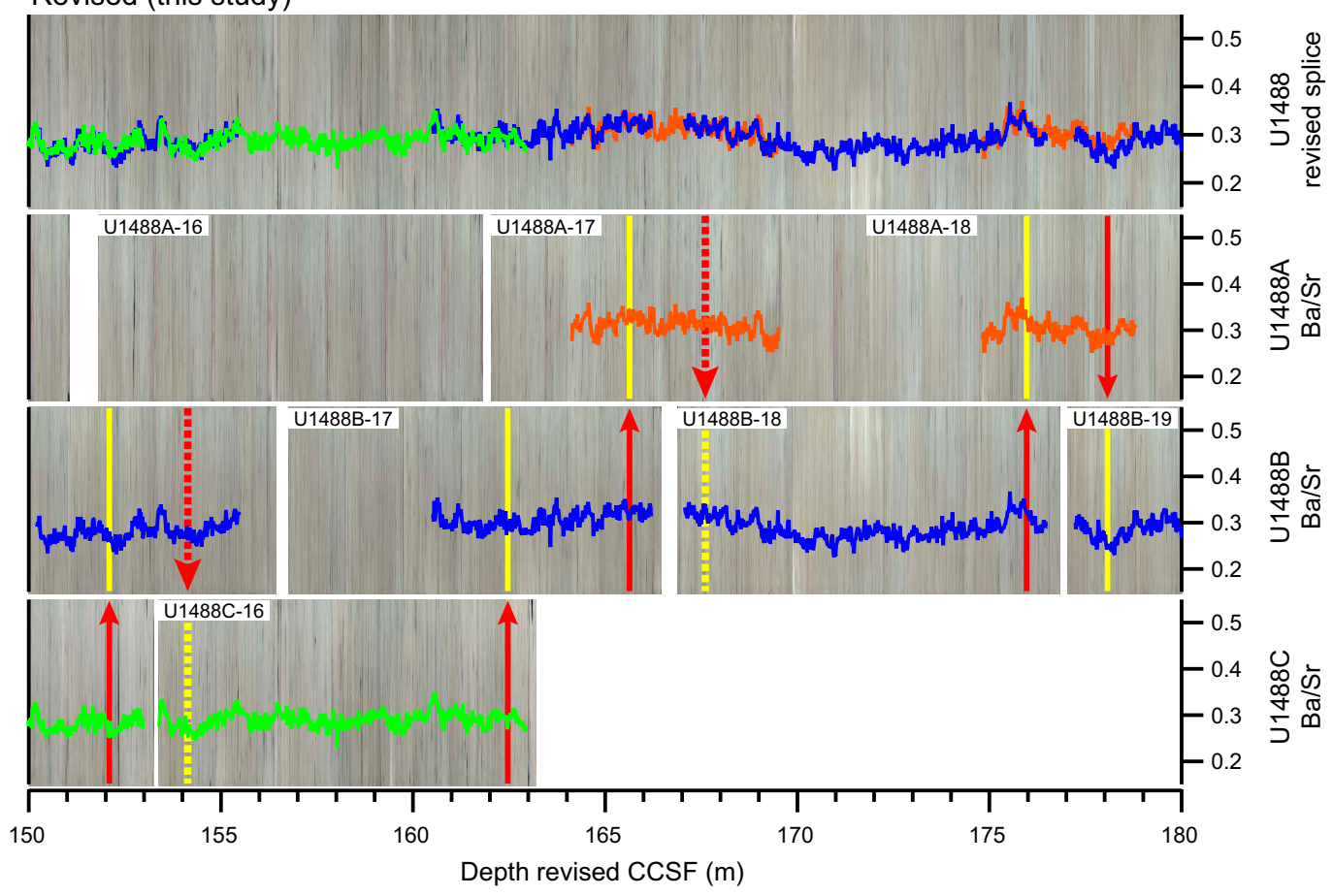


Figure F3 (continued).

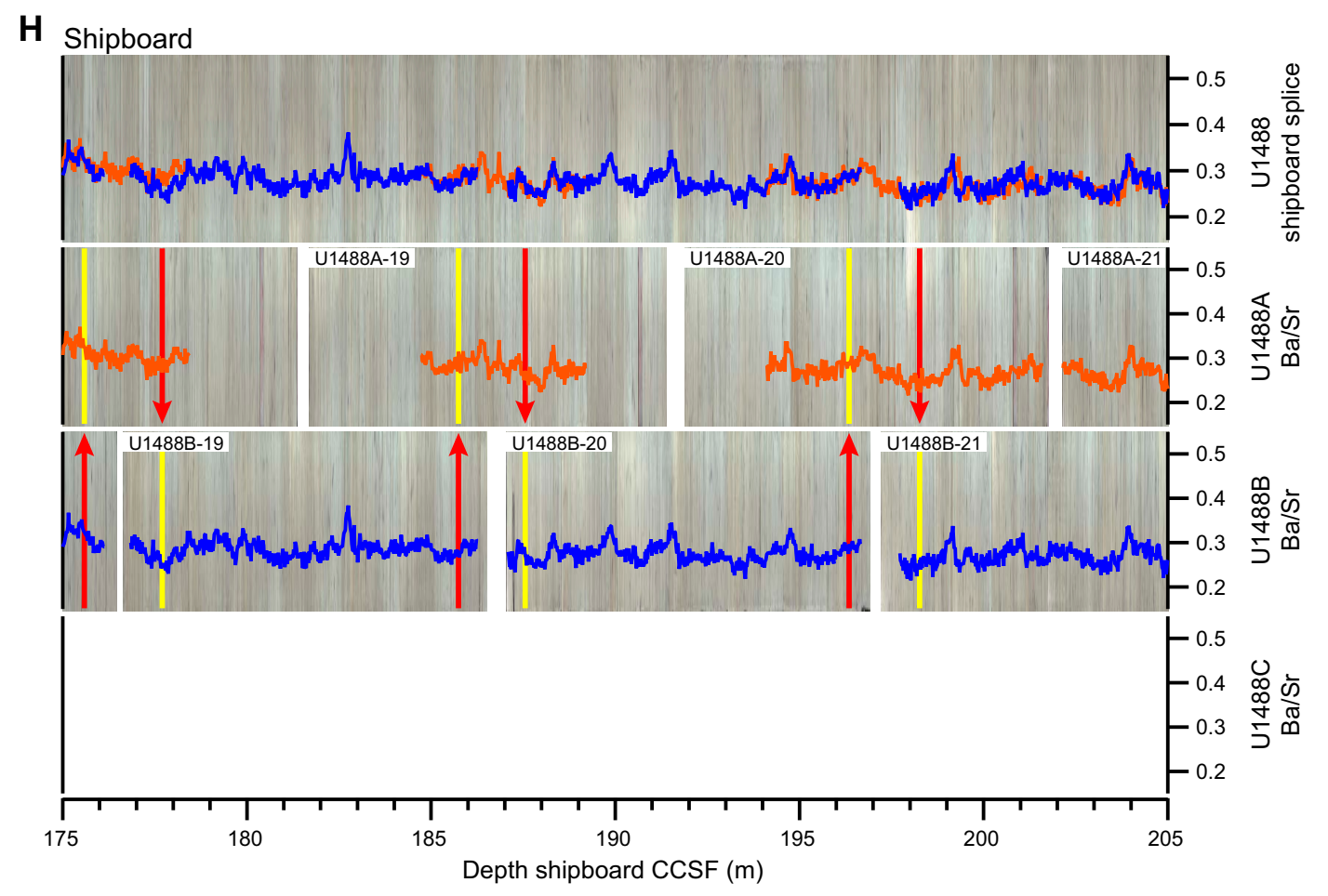

Revised (this study)

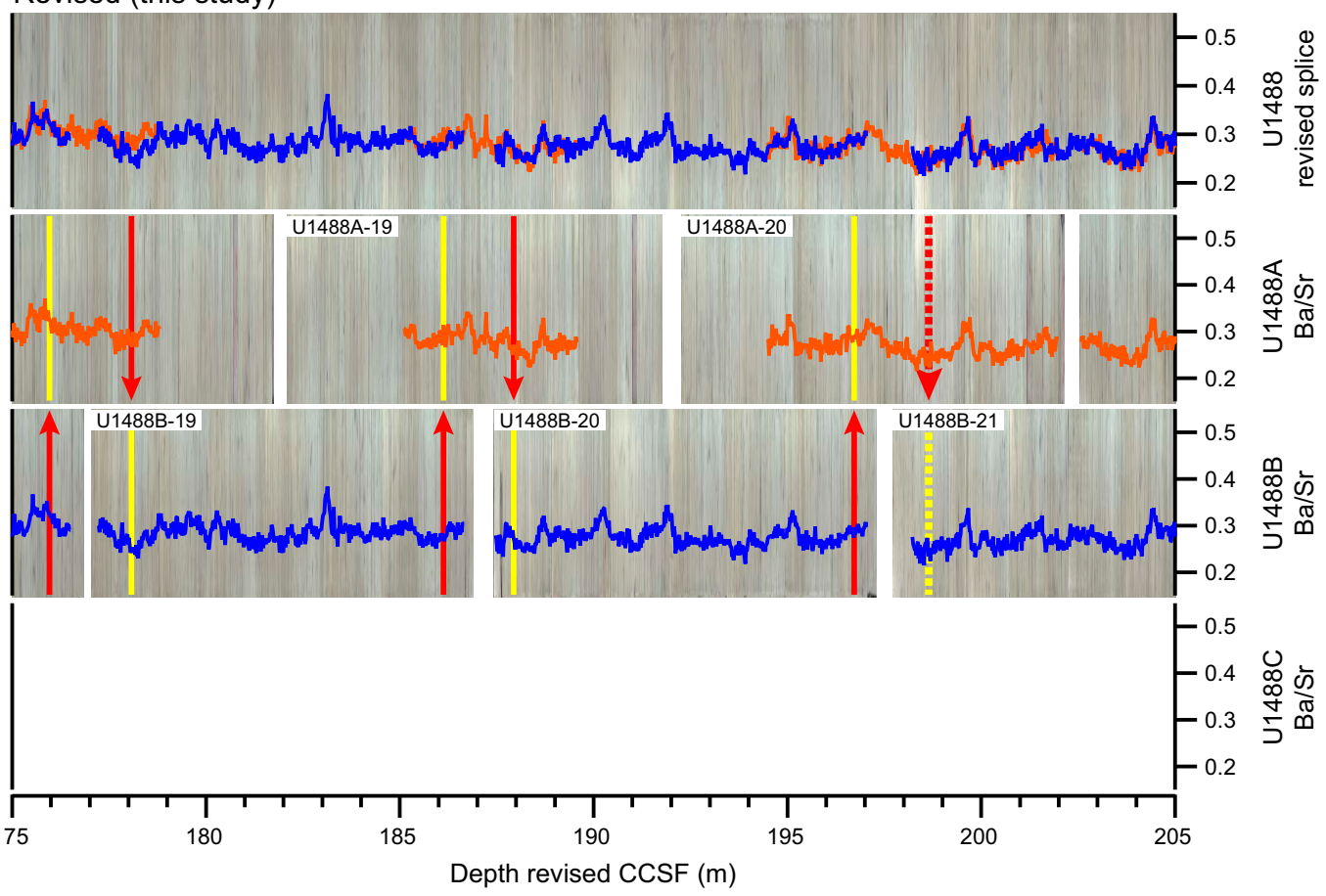


Figure F3 (continued).

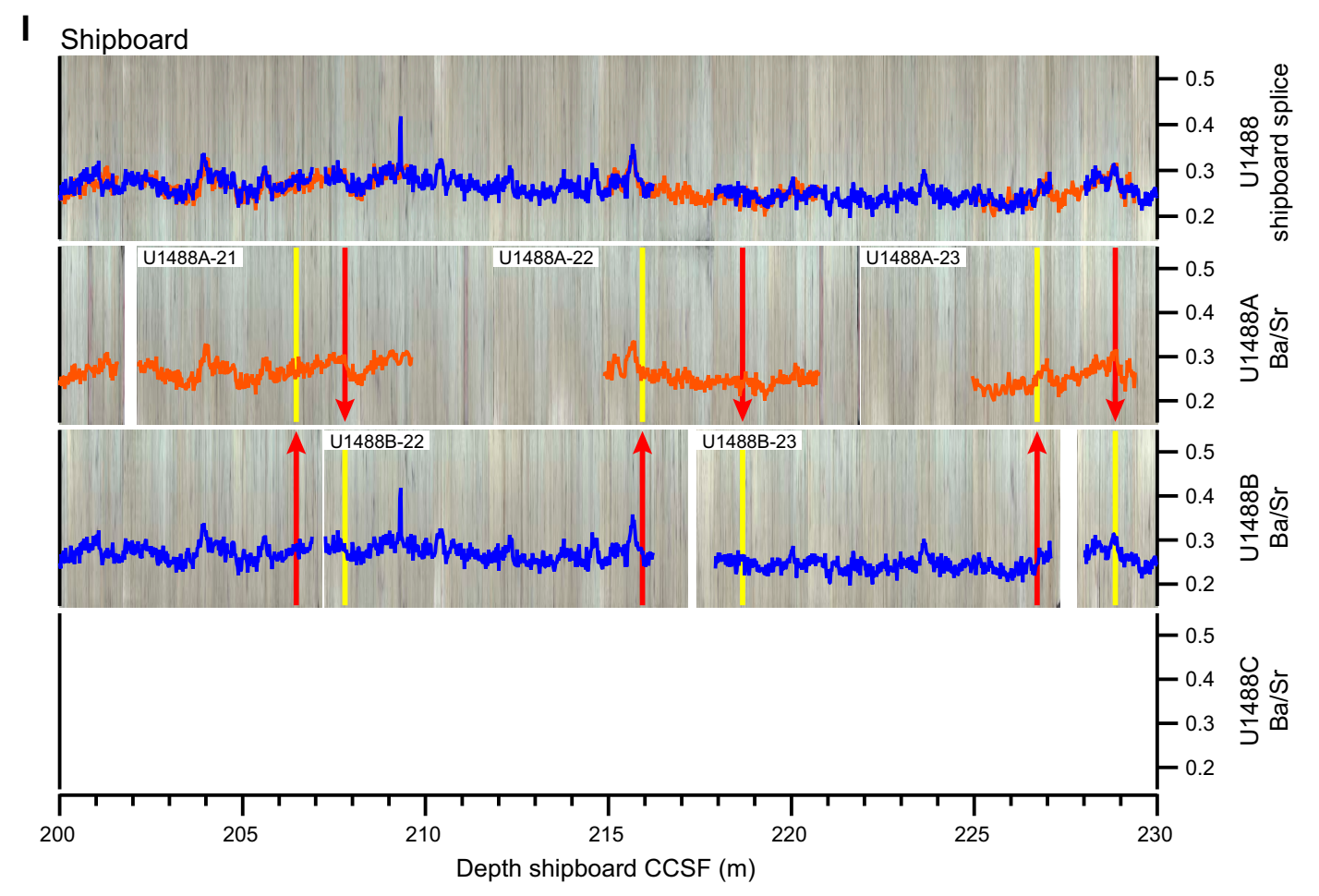

Revised (this study)

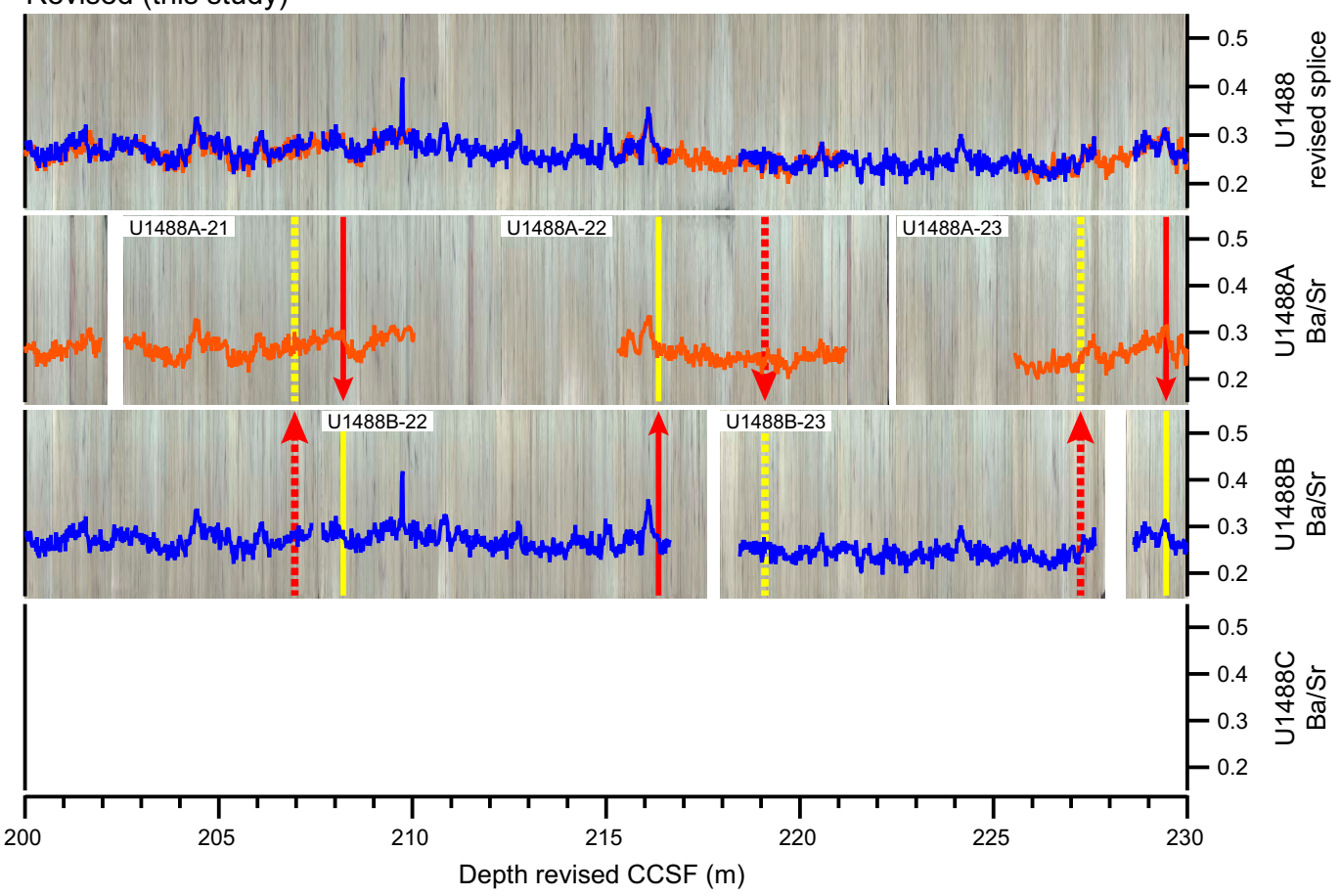


Figure F3 (continued).

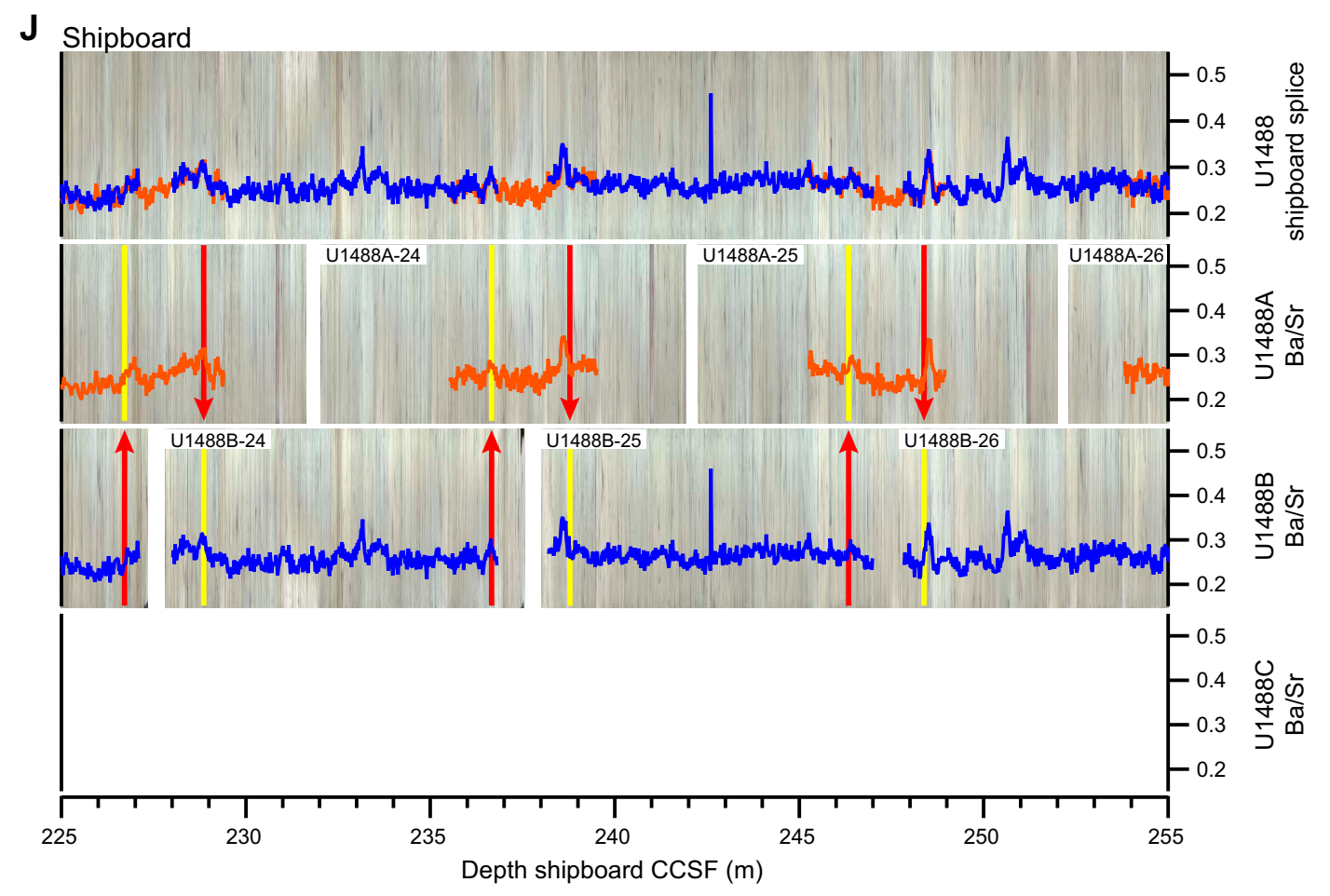

Revised (this study)
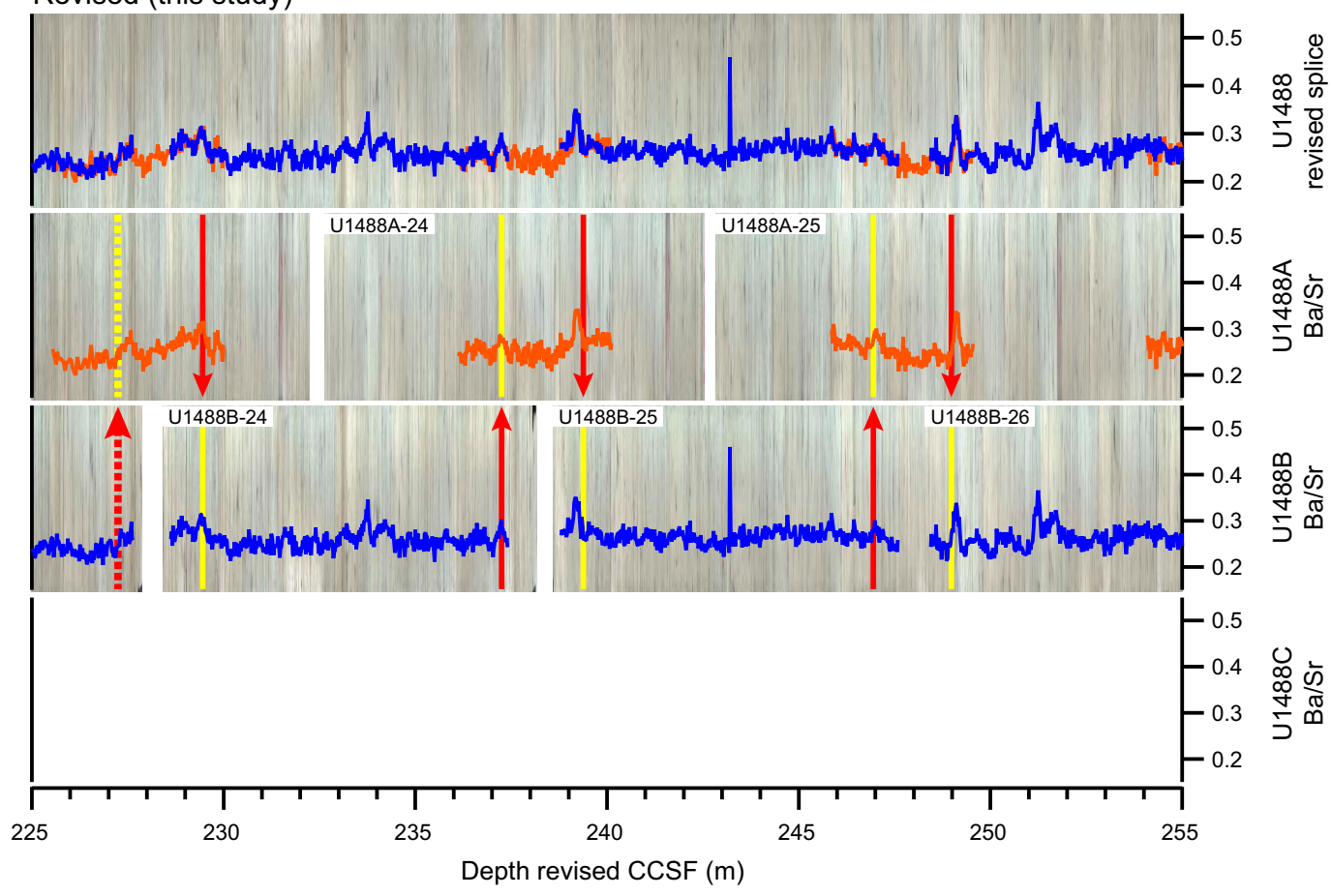
Figure F3 (continued).

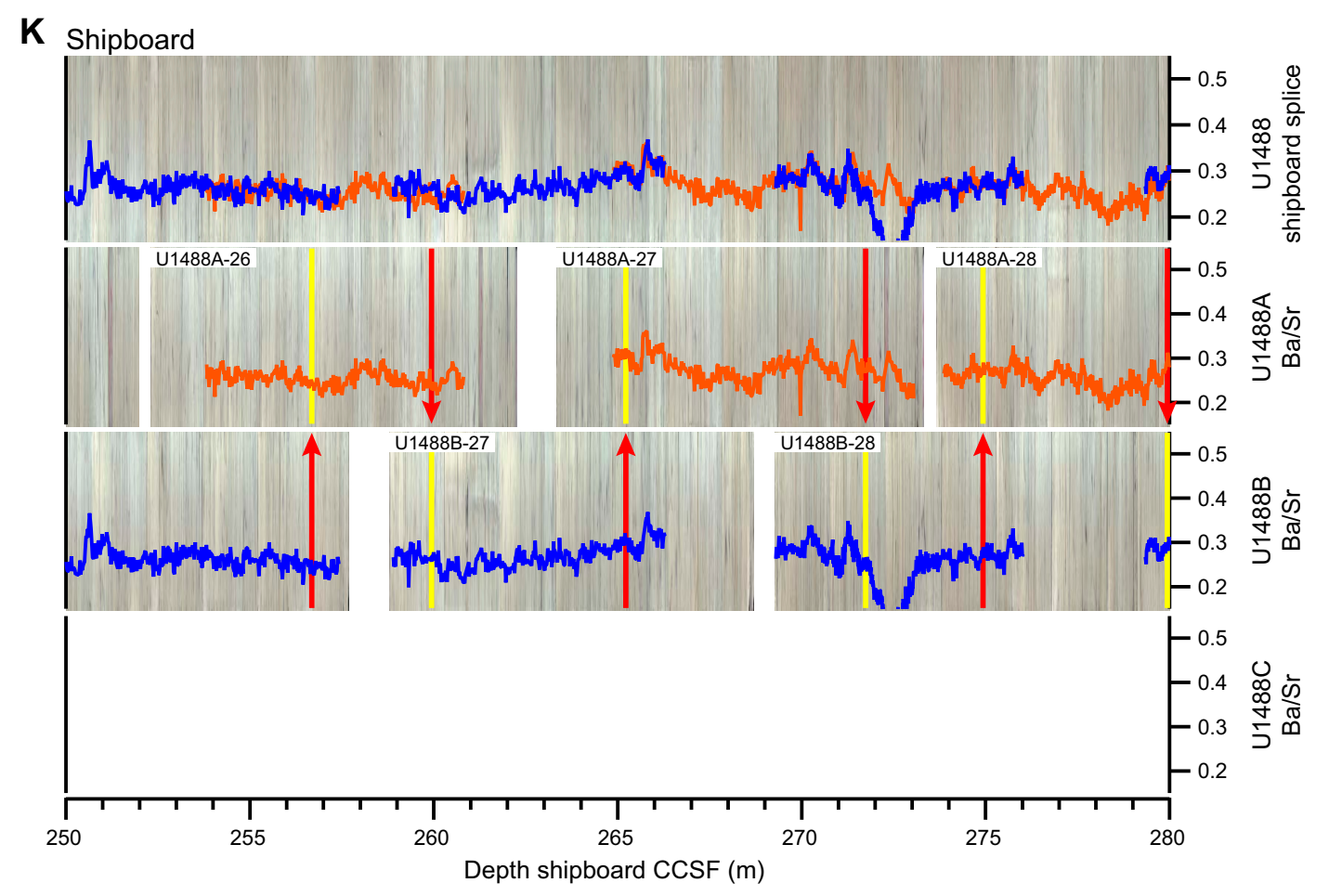

Revised (this study)
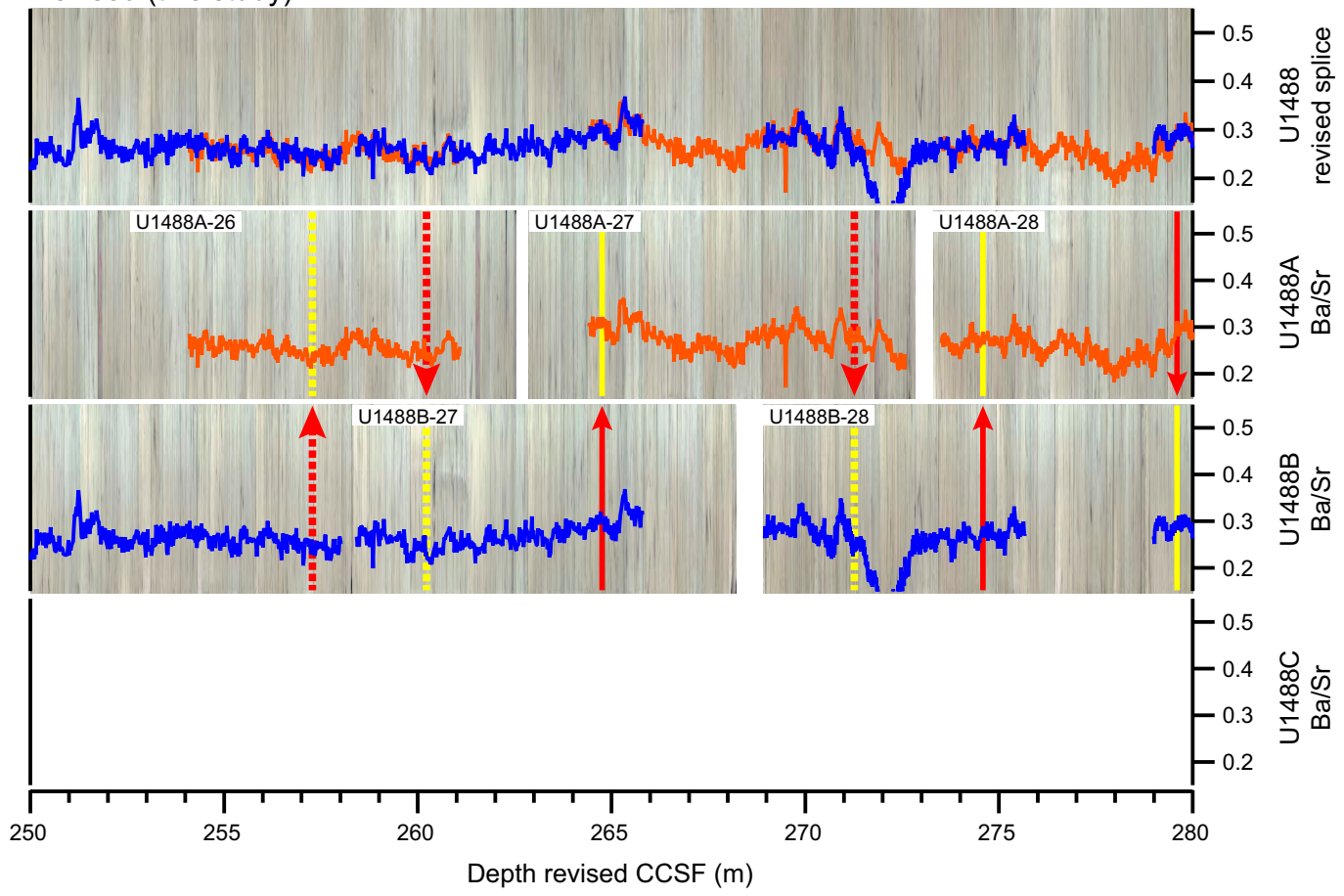
Figure F3 (continued).
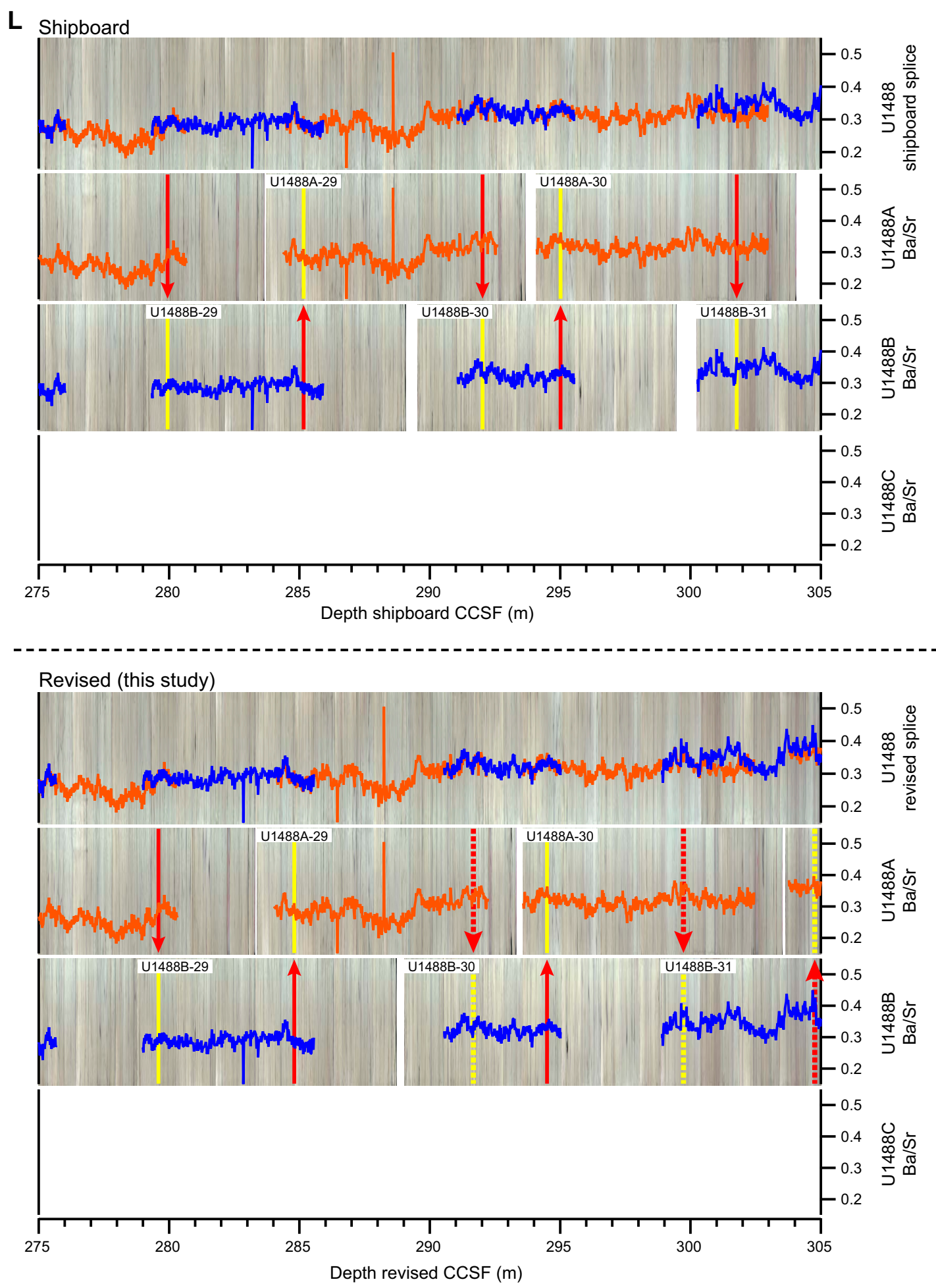
Figure F3 (continued).

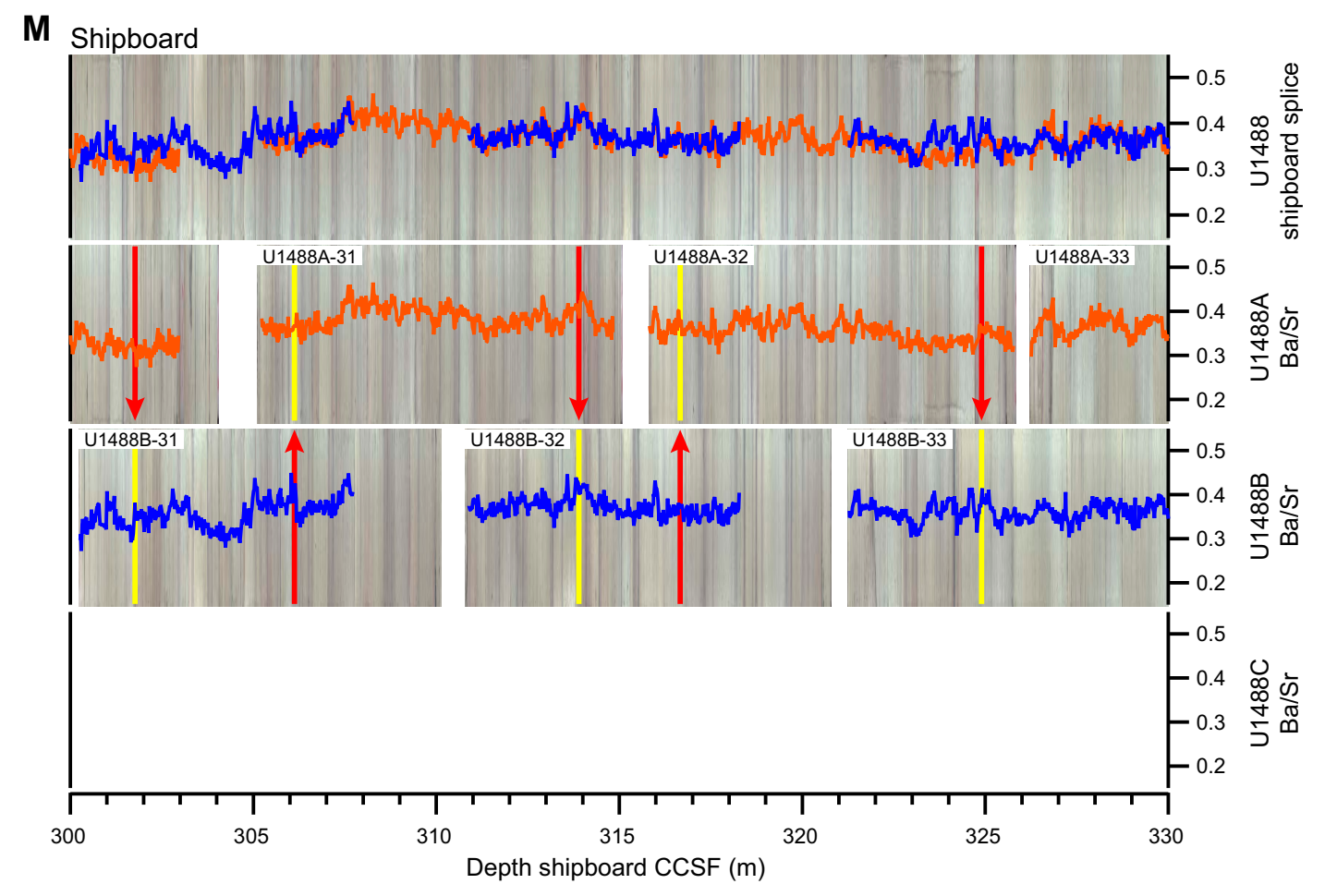

Revised (this study)

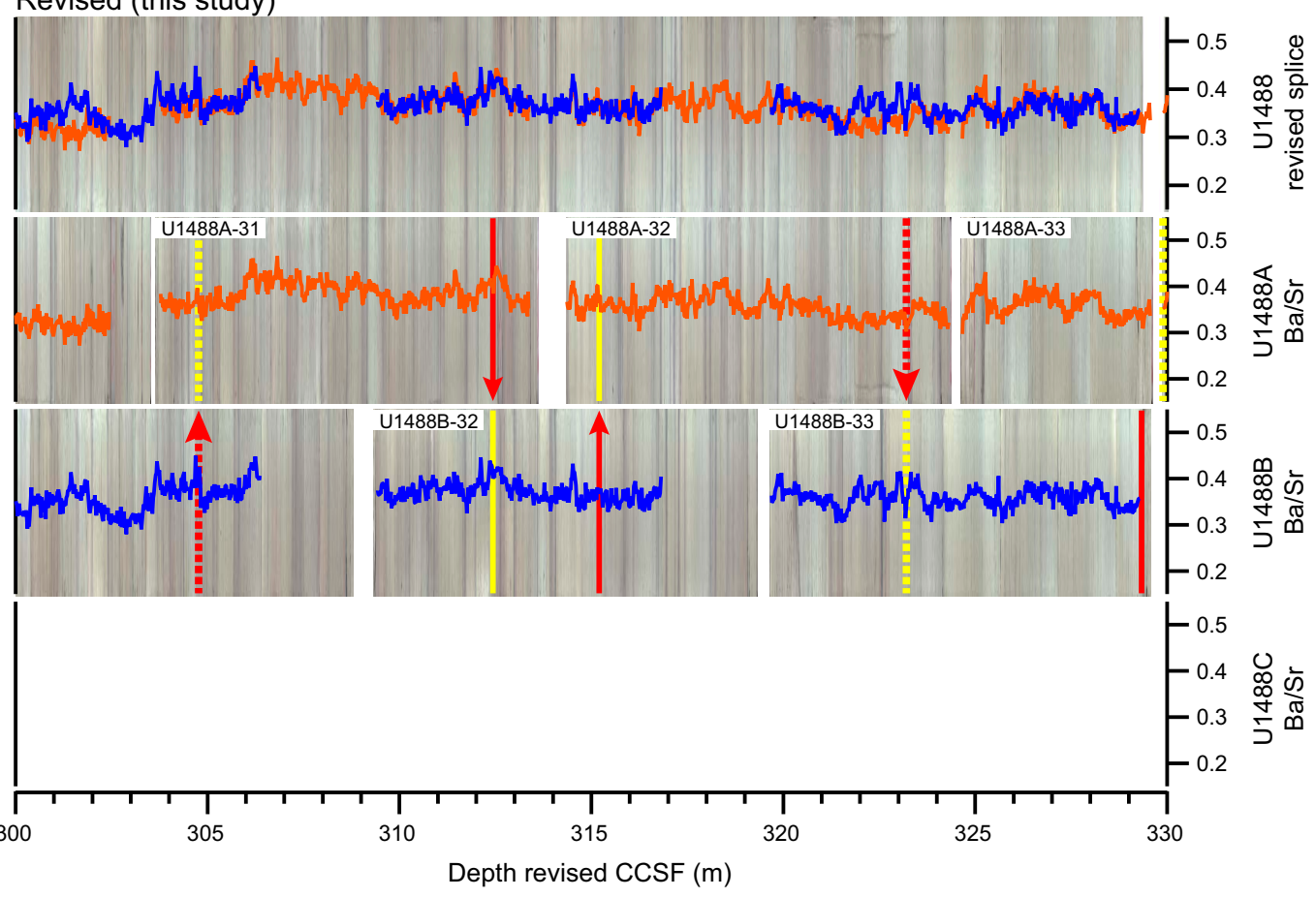


Figure F3 (continued).

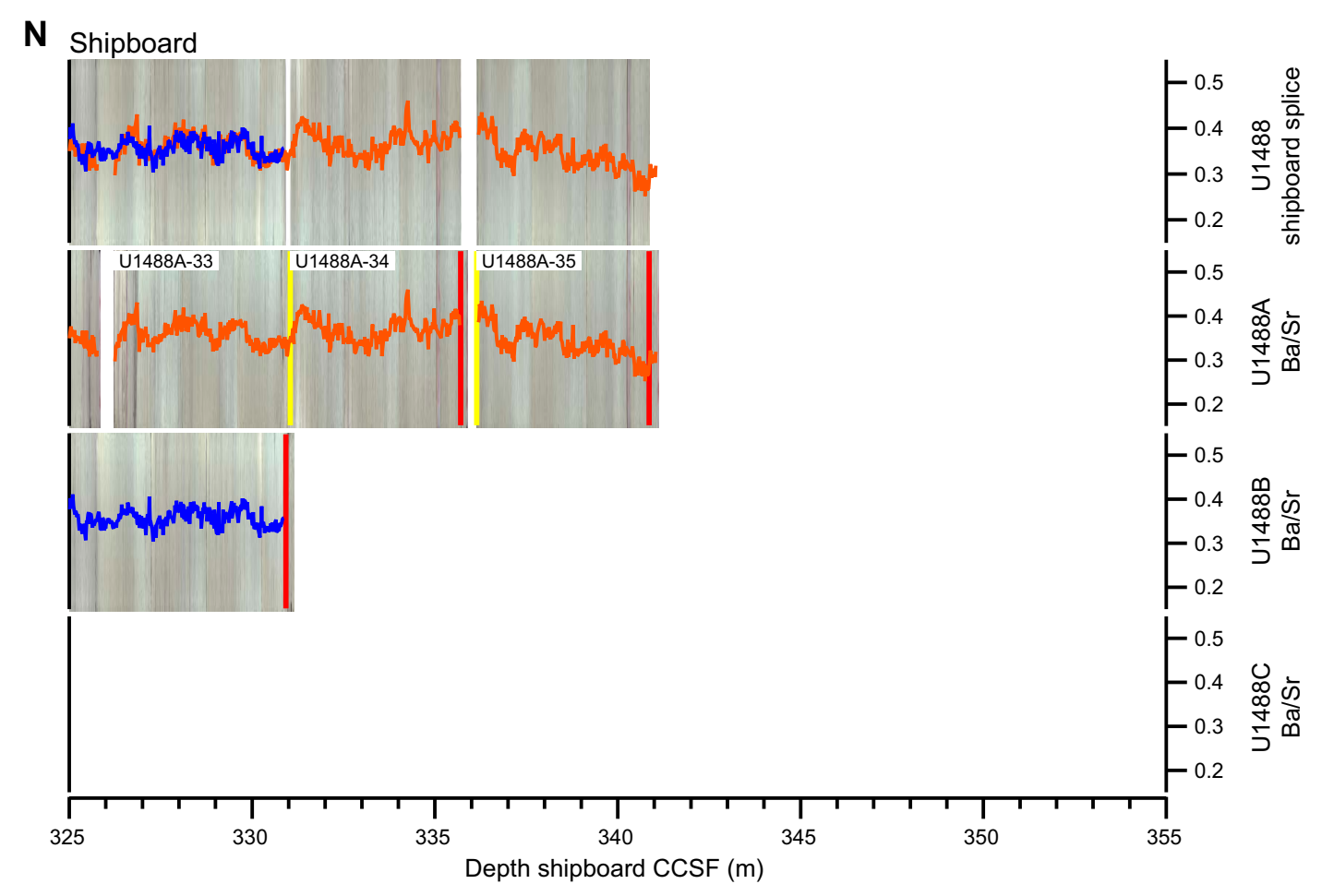

Revised (this study)

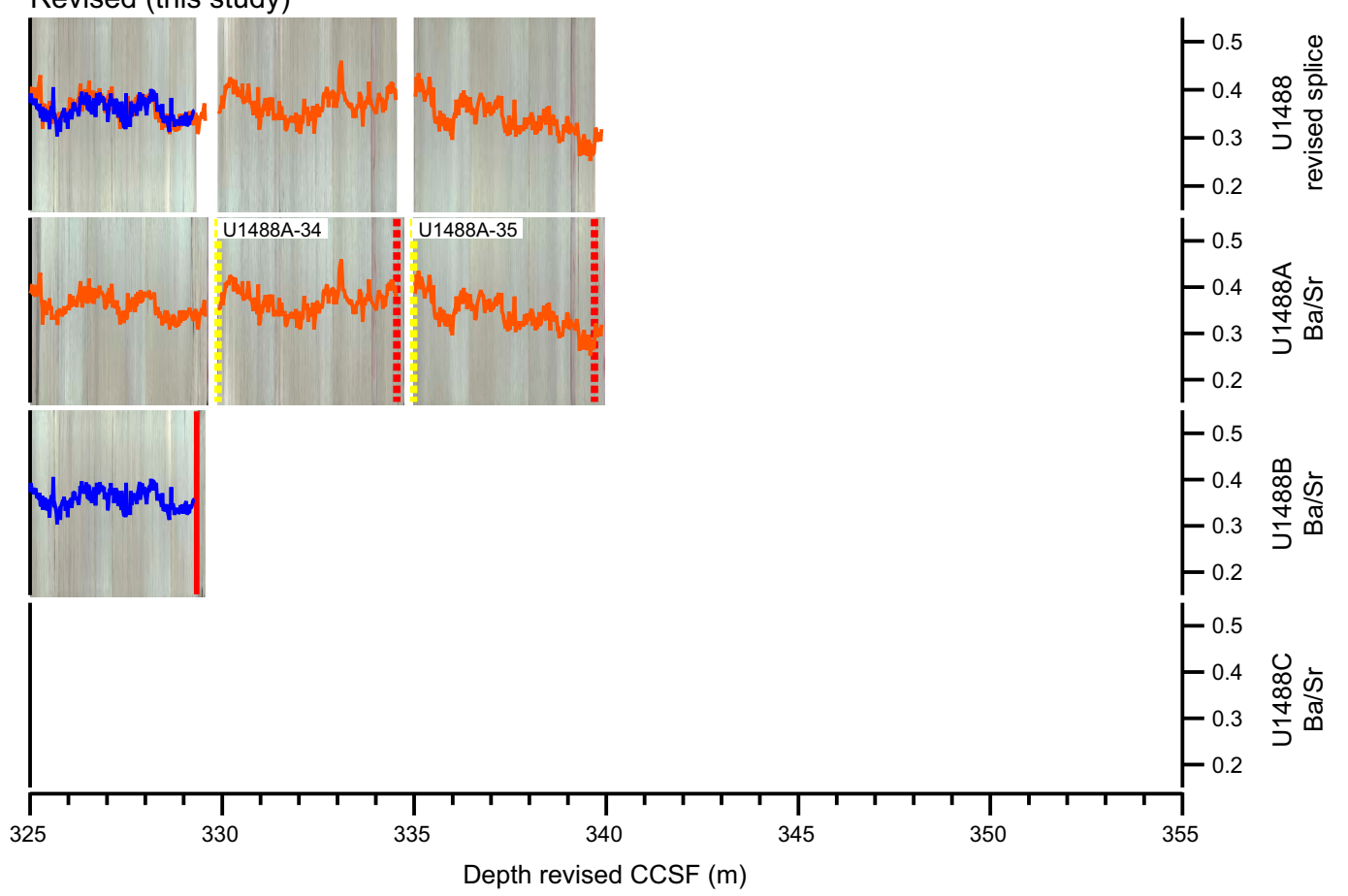


and Patrizia Geprägs for their help with core handling and Vera Lukies for her help with XRF core scanning. We thank Peter Blum for his thorough review, which helped us to improve the data report.

This research used samples and data provided by IODP, which is sponsored by the US National Science Foundation and participating countries. A.J. Drury and the XRF core scanning were funded by a MARUM Incentive Fund Award to A.J. Drury. A.J. Drury was additionally funded by DFG (Project Number 408101468) and by European Union's Horizon 2020 research and innovation programme under the Marie Sklodowska-Curie grant agreement No 796220. D. Kulhanek was funded by IODP JRSO NSF grant Number 1326927. Data are archived as supplementary tables in this volume and are available with the entire core and splice images in the PANGAEA database: https://www.pangaea.de.

\section{References}

Drury, A.J., Westerhold, T., Hodell, D., and Röhl, U., 2018. Reinforcing the North Atlantic backbone: revision and extension of the composite splice at ODP Site 982. Climate of the Past, 14(3):321-338. https://doi.org/10.5194/cp-14-321-2018

Hagelberg, T., Shackleton, N., Pisias, N., and the Shipboard Scientific Party, 1992. Development of composite depth sections for Sites 844 through 854. In Mayer, L., Pisias, N., Janecek, T., et al., Proceedings of the Ocean Drilling Program, Initial Reports. 138: College Station, TX (Ocean Drilling Program), 79-85. https://doi.org/10.2973/odp.proc.ir.138.105.1992

Hagelberg, T.K., Pisias, N.G., Shackleton, N.J., Mix, A.C., and Harris, S., 1995 Refinement of a high-resolution, continuous sedimentary section for studying equatorial Pacific Ocean paleoceanography, Leg 138. In Pisias, N.G., Mayer, L.A., Janecek, T.R., Palmer-Julson, A., and van Andel, T.H. (Eds.), Proceedings of the Ocean Drilling Program, Scientific Results. 138: College Station, TX (Ocean Drilling Program). https://doi.org/10.2973/odp.proc.sr.138.103.1995

Rosenthal, Y., Holbourn, A.E., Kulhanek, D.K., and the Expedition 363 Scientists, 2017. Expedition 363 Preliminary Report: Western Pacific Warm Pool: International Ocean Discovery Program https://doi.org/10.14379/iodp.pr.363.2017

Rosenthal, Y., Holbourn, A.E., Kulhanek, D.K., Aiello, I.W., Babila, T.L., Bayon, G., Beaufort, L., Bova, S.C., Chun, J.-H., Haowen, D., Drury, A.J., Dunkley Jones, T., Eichler, P.P.B., Fernando, A.G.S., Gibson, K.A., Hatfield, R.G., Johnson, D.L., Kumagai, Y., Tiegang, L., Linsley, B.K., Meinicke, N., Mountain, G.S., Opdyke, B.N., Pearson, P.N., Poole, C.R., Ravelo, A.C., Sagawa, T., Schmitt, A., Wurtzel, J.B., Jian, X., Yamamoto, M., and Zhang, Y.G., 2018a. Expedition 363 methods. In Rosenthal, Y., Holbourn, A.E., Kulhanek, D.K., and the Expedition 363 Scientists, Western Pacific Warm Pool. Proceedings of the International Ocean Discovery Program, 363: College Station, TX (International Ocean Discovery Program). https://doi.org/10.14379/iodp.proc.363.102.2018
Rosenthal, Y., Holbourn, A.E., Kulhanek, D.K., Aiello, I.W., Babila, T.L., Bayon, G., Beaufort, L., Bova, S.C., Chun, J.-H., Haowen, D., Drury, A.J., Dunkley Jones, T., Eichler, P.P.B., Fernando, A.G.S., Gibson, K.A., Hatfield, R.G., Johnson, D.L., Kumagai, Y., Tiegang, L., Linsley, B.K., Meinicke, N., Mountain, G.S., Opdyke, B.N., Pearson, P.N., Poole, C.R., Ravelo, A.C., Sagawa, T., Schmitt, A., Wurtzel, J.B., Jian, X., Yamamoto, M., and Zhang, Y.G., 2018b. Expedition 363 summary. In Rosenthal, Y., Holbourn, A.E., Kulhanek, D.K., and the Expedition 363 Scientists, Western Pacific Warm Pool. Proceedings of the International Ocean Discovery Program, 363: College Station, TX (International Ocean Discovery Program). https://doi.org/10.14379/iodp.proc.363.101.2018

Rosenthal, Y., Holbourn, A.E., Kulhanek, D.K., Aiello, I.W., Babila, T.L., Bayon, G., Beaufort, L., Bova, S.C., Chun, J.-H., Haowen, D., Drury, A.J., Dunkley Jones, T., Eichler, P.P.B., Fernando, A.G.S., Gibson, K.A., Hatfield, R.G., Johnson, D.L., Kumagai, Y., Tiegang, L., Linsley, B.K., Meinicke, N., Mountain, G.S., Opdyke, B.N., Pearson, P.N., Poole, C.R., Ravelo, A.C., Sagawa, T., Schmitt, A., Wurtzel, J.B., Jian, X., Yamamoto, M., and Zhang, Y.G., 2018c. Site U1488. In Rosenthal, Y., Holbourn, A.E., Kulhanek, D.K., and the Expedition 363 Scientists, Western Pacific Warm Pool. Proceedings of the International Ocean Discovery Program, 363: College Station, TX (International Ocean Discovery Program). https://doi.org/10.14379/iodp.proc.363.109.2018

Rosenthal, Y., Holbourn, A.E., Kulhanek, D.K., and the Expedition 363 Scientists, 2018d. Supplementary material, https://doi.org/10.14379/iodp.proc.363supp.2018. Supplement to Rosenthal, Y., Holbourn, A.E., Kulhanek, D.K., and the Expedition 363 Scientists, Western Pacific Warm Pool. Proceedings of the International Ocean Discovery Program, 363: College Station, TX (International Ocean Discovery Program). https://doi.org/10.14379/iodp.proc.363.2018

Ruddiman, W.F., Cameron, D., and Clement, B.M., 1987. Sediment disturbance and correlation of offset holes drilled with the hydraulic piston corer - Leg 94. In Ruddiman, W.F., Kidd, R. B., Thomas, E., et al., Initial Reports of the Deep Sea Drilling Project, 94: Washington, DC (US Government Printing Office), 615-634. https://doi.org/10.2973/dsdp.proc.94.111.1987

van Peer, T.E., Liebrand, D., Xuan, C., Lippert, P.C., Agnini, C., Blum, N., Blum, P., Bohaty, S.M., Bown, P.R., Greenop, R., Kordesch, W.E.C., Leonhardt, D., Friedrich, O., and Wilson, P.A., 2017. Data report: revised composite depth scale and splice for IODP Site U1406. In Norris, R.D., Wilson, P.A., Blum, P., and the Expedition 342 Scientists, Proceedings of the Integrated Ocean Drilling Program, 342: College Station, TX (Integrated Ocean Drilling Program). https://doi.org/10.2204/iodp.proc.342.202.2017

Wilkens, R.H., Dickens, G.R., Tian, J., Backman, J., and the Expedition 320/321 Scientists, 2013. Data report: revised composite depth scales for Sites U1336, U1337, and U1338. Proceedings of the Integrated Ocean Drilling Program, 320/321. https://doi.org/10.2204/iodp.proc.320321.209.2013

Wilkens, R.H., Westerhold, T., Drury, A.J., Lyle, M., Gorgas, T., and Tian, J., 2017. Revisiting the Ceara Rise, equatorial Atlantic Ocean: isotope stratigraphy of ODP Leg 154 from 0 to $5 \mathrm{Ma}$. Climate of the Past, 13(7):779793. https://doi.org/10.5194/cp-13-779-2017 
Table T1. Affine table for Site U1488. ${ }^{*}=$ uncertain tie point. GF $=$ growth factor. MS = magnetic susceptibility, GRA $=$ bulk density, PWL $=P$-wave, $\mathrm{L}^{*}=$ luminosity, NGR = natural gamma radiation, XRF = X-ray fluorescence. (Continued on next page.) Download table in CSV format.

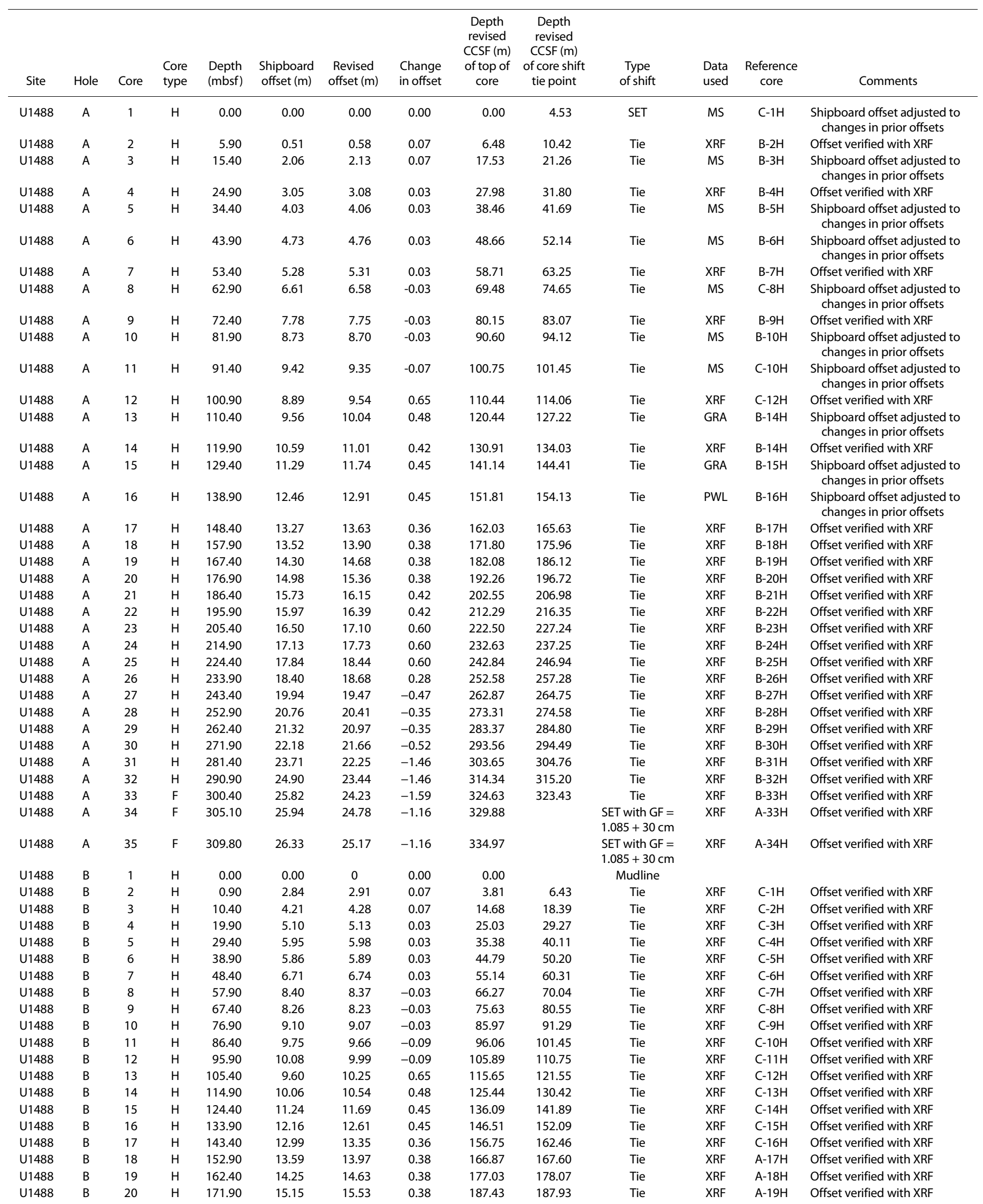


Table T1 (continued).

\begin{tabular}{|c|c|c|c|c|c|c|c|c|c|c|c|c|c|}
\hline Site & Hole & Core & $\begin{array}{l}\text { Core } \\
\text { type }\end{array}$ & $\begin{array}{l}\text { Depth } \\
\text { (mbsf) }\end{array}$ & $\begin{array}{l}\text { Shipboard } \\
\text { offset }(m)\end{array}$ & $\begin{array}{l}\text { Revised } \\
\text { offset }(\mathrm{m})\end{array}$ & $\begin{array}{l}\text { Change } \\
\text { in offset }\end{array}$ & $\begin{array}{l}\text { Depth } \\
\text { revised } \\
\text { CCSF }(m) \\
\text { of top of } \\
\text { core }\end{array}$ & $\begin{array}{l}\text { Depth } \\
\text { revised } \\
\text { CCSF }(\mathrm{m}) \\
\text { of core shift } \\
\text { tie point }\end{array}$ & $\begin{array}{l}\text { Type } \\
\text { of shift }\end{array}$ & $\begin{array}{l}\text { Data } \\
\text { used }\end{array}$ & $\begin{array}{l}\text { Reference } \\
\text { core }\end{array}$ & Comments \\
\hline U1488 & B & 21 & $\mathrm{H}$ & 181.40 & 15.82 & 16.32 & 0.50 & 197.72 & 198.64 & Tie & XRF & $\mathrm{A}-2 \mathrm{OH}$ & Offset verified with XRF \\
\hline U1488 & B & 22 & $\mathrm{H}$ & 190.90 & 16.34 & 16.76 & 0.42 & 207.66 & 208.21 & Tie & XRF & $\mathrm{A}-21 \mathrm{H}$ & Offset verified with XRF \\
\hline U1488 & B & 23 & $\mathrm{H}$ & 200.40 & 17.02 & 17.55 & 0.53 & 217.95 & 219.09 & Tie & XRF & $\mathrm{A}-22 \mathrm{H}$ & Offset verified with XRF \\
\hline U1488 & B & 24 & $\mathrm{H}$ & 209.90 & 17.92 & 18.52 & 0.60 & 228.42 & 229.45 & Tie & XRF & $\mathrm{A}-23 \mathrm{H}$ & Offset verified with XRF \\
\hline U1488 & B & 25 & $\mathrm{H}$ & 219.40 & 18.60 & 19.2 & 0.60 & 238.60 & 239.38 & Tie & XRF & $\mathrm{A}-24 \mathrm{H}$ & Offset verified with XRF \\
\hline U1488 & B & 26 & $\mathrm{H}$ & 228.90 & 18.80 & 19.4 & 0.60 & 248.30 & 248.98 & Tie & XRF & $\mathrm{A}-25 \mathrm{H}$ & Offset verified with XRF \\
\hline U1488 & B & 27 & $\mathrm{H}$ & 238.40 & 20.39 & 19.92 & -0.47 & 258.32 & 260.22 & Tie & XRF & $\mathrm{A}-26 \mathrm{H}$ & Offset verified with XRF \\
\hline U1488 & B & 28 & $\mathrm{H}$ & 247.90 & 21.38 & 21.03 & -0.35 & 268.93 & 271.26 & Tie & XRF & $\mathrm{A}-27 \mathrm{H}$ & Offset verified with XRF \\
\hline U1488 & B & 29 & $\mathrm{H}$ & 257.40 & 21.74 & 21.39 & -0.35 & 278.79 & 279.59 & Tie & XRF & $\mathrm{A}-28 \mathrm{H}$ & Offset verified with XRF \\
\hline U1488 & B & 30 & $\mathrm{H}$ & 266.90 & 22.64 & 22.12 & -0.52 & 289.02 & 291.67 & Tie & XRF & $\mathrm{A}-29 \mathrm{H}$ & Offset verified with XRF \\
\hline U1488 & B & 31 & $\mathrm{H}$ & 276.40 & 23.84 & 22.48 & -1.36 & 298.88 & 299.73 & Tie & XRF & $\mathrm{A}-30 \mathrm{H}$ & Offset verified with XRF \\
\hline U1488 & B & 32 & $\mathrm{H}$ & 285.90 & 24.89 & 23.43 & -1.46 & 309.33 & 312.43 & Tie & XRF & $\mathrm{A}-31 \mathrm{H}$ & Offset verified with XRF \\
\hline U1488 & B & 33 & $\mathrm{H}$ & 295.40 & 25.83 & 24.24 & -1.59 & 319.64 & 323.43 & Tie & XRF & $\mathrm{A}-32 \mathrm{H}$ & $\begin{array}{l}\text { *Offset verified with XRF; } \\
\text { Difficult to align tie point }\end{array}$ \\
\hline U1488 & C & 1 & $\mathrm{H}$ & 0.00 & 0.00 & 0 & 0.00 & 0.00 & & Mudline & & & \\
\hline U1488 & $C$ & 2 & $\mathrm{H}$ & 7.30 & 2.29 & 2.36 & 0.07 & 9.66 & 10.42 & Tie & XRF & $\mathrm{B}-2 \mathrm{H}$ & Offset verified with XRF \\
\hline U1488 & $\mathrm{C}$ & 3 & $\mathrm{H}$ & 16.80 & 3.34 & 3.37 & 0.03 & 20.17 & 21.26 & Tie & XRF & B-3H & Offset verified with XRF \\
\hline U1488 & $C$ & 4 & $\mathrm{H}$ & 26.30 & 4.66 & 4.69 & 0.03 & 30.99 & 31.80 & Tie & XRF & B-4H & Offset verified with XRF \\
\hline U1488 & $\mathrm{C}$ & 5 & $\mathrm{H}$ & 35.80 & 5.29 & 5.32 & 0.03 & 41.12 & 41.69 & Tie & XRF & $\mathrm{B}-5 \mathrm{H}$ & Offset verified with XRF \\
\hline U1488 & C & 6 & $\mathrm{H}$ & 45.30 & 5.98 & 6.01 & 0.03 & 51.31 & 52.14 & Tie & XRF & $\mathrm{B}-6 \mathrm{H}$ & Offset verified with XRF \\
\hline U1488 & $C$ & 7 & $\mathrm{H}$ & 54.80 & 6.10 & 6.13 & 0.03 & 60.93 & 63.25 & Tie & XRF & B-7H & Offset verified with XRF \\
\hline U1488 & C & 8 & $\mathrm{H}$ & 64.30 & 7.57 & 7.54 & -0.03 & 71.84 & 73.65 & Tie & XRF & $\mathrm{B}-8 \mathrm{H}$ & Offset verified with XRF \\
\hline U1488 & C & 9 & $\mathrm{H}$ & 73.80 & 8.43 & 8.34 & -0.09 & 82.14 & 83.07 & Tie & XRF & $\mathrm{B}-9 \mathrm{H}$ & Offset verified with XRF \\
\hline U1488 & $C$ & 10 & $\mathrm{H}$ & 83.30 & 9.60 & 9.53 & -0.07 & 92.83 & 94.12 & Tie & XRF & B-10H & Offset verified with XRF \\
\hline U1488 & $C$ & 11 & $\mathrm{H}$ & 92.80 & 10.20 & 10.11 & -0.09 & 102.91 & 104.78 & Tie & XRF & B-11H & Offset verified with XRF \\
\hline U1488 & $C$ & 12 & $\mathrm{H}$ & 102.30 & 10.11 & 10.76 & 0.65 & 113.06 & 113.47 & Tie & XRF & B-12H & $\begin{array}{l}\text { *Offset verified with XRF; } \\
\text { Overlap is not very long }\end{array}$ \\
\hline U1488 & C & 13 & $\mathrm{H}$ & 111.80 & 10.53 & 11.01 & 0.48 & 122.81 & 123.45 & Tie & XRF & B-13H & Offset verified with XRF \\
\hline U1488 & C & 14 & $\mathrm{H}$ & 121.30 & 11.69 & 12.14 & 0.45 & 133.44 & 134.13 & Tie & XRF & B-14H & Offset verified with XRF \\
\hline U1488 & $C$ & 15 & $\mathrm{H}$ & 130.80 & 12.08 & 12.53 & 0.45 & 143.33 & 144.41 & Tie & XRF & B-15H & Offset verified with XRF \\
\hline U1488 & $\mathrm{C}$ & 16 & $\mathrm{H}$ & 140.30 & 12.71 & 13.07 & 0.36 & 153.37 & 154.13 & Tie & XRF & B-16H & Offset verified with XRF \\
\hline
\end{tabular}


Table T2. Revised splice interval table, Site U1488. CSF = core depth below seafloor, $\mathrm{mbsf}=$ meters below seafloor. MS = magnetic susceptibility, GRA = gamma ray attenuation bulk density, $\mathrm{PWL}=P$-wave velocity, $\mathrm{L}^{*}=$ luminosity, $\mathrm{NGR}=$ natural gamma radiation, $\mathrm{XRF}=\mathrm{X}$-ray fluorescence. Status column indicates how a tie point was changed: "Shipboard - verified" was verified using the XRF data but not changed, "Shipboard - adjusted" indicates small ( 1 cm) changes to the interval and CSF of the original shipboard tie point to account for the rounding of the shipboard cumulative core offsets to the nearest centimeter, "Revised" indicates splice tie points that were revised to accommodate changes to the composite depth scale. The Comments column specifies which tie point was changed. (Continued on next two pages.) Download in CSV format.

\begin{tabular}{|c|c|c|c|c|c|c|c|c|c|c|c|c|c|c|c|c|}
\hline \multirow[b]{2}{*}{ Site } & \multirow[b]{2}{*}{ Hole } & \multirow[b]{2}{*}{ Core } & \multirow[b]{2}{*}{$\begin{array}{l}\text { Core } \\
\text { type }\end{array}$} & \multicolumn{4}{|c|}{ Top of revised splice interval } & \multicolumn{4}{|c|}{$\begin{array}{l}\text { Bottom of revised splice } \\
\text { interval }\end{array}$} & \multirow[b]{2}{*}{$\begin{array}{l}\text { Splice } \\
\text { type }\end{array}$} & \multirow[b]{2}{*}{$\begin{array}{l}\text { Data used } \\
\text { for tie point }\end{array}$} & \multirow[b]{2}{*}{$\begin{array}{l}\text { Other data } \\
\text { needed to } \\
\text { verify tie }\end{array}$} & \multirow[b]{2}{*}{ Status } & \multirow[b]{2}{*}{ Comment } \\
\hline & & & & Section & $\begin{array}{l}\text { Offset } \\
(\mathrm{cm})\end{array}$ & $\begin{array}{l}\text { Depth } \\
\text { (mbsf) }\end{array}$ & $\begin{array}{l}\text { Depth } \\
\text { CCSF } \\
(\mathrm{m})\end{array}$ & Section & $\begin{array}{l}\text { Offset } \\
(\mathrm{cm})\end{array}$ & $\begin{array}{l}\text { Depth } \\
\text { (mbsf) }\end{array}$ & $\begin{array}{l}\text { Depth } \\
\text { CCSF } \\
(\mathrm{m})\end{array}$ & & & & & \\
\hline U1488 & C & 1 & $\mathrm{H}$ & 1 & 0 & 0 & 0 & 5 & 36 & 6.36 & 6.36 & ANCHOR & MS & $\begin{array}{l}\text { verified by } \\
\text { XRF }\end{array}$ & $\begin{array}{l}\text { Shipboard - } \\
\text { verified }\end{array}$ & \\
\hline U1488 & B & 2 & $\mathrm{H}$ & 2 & 105 & 3.45 & 6.36 & 5 & 61 & 7.51 & 10.42 & Tie & $\mathrm{XRF}$ & & Revised & $\begin{array}{l}\text { C-1 to B-2 tie revised; Bottom B-2 } \\
\text { interval and CSF adjusted by } 1 \mathrm{~cm}\end{array}$ \\
\hline U1488 & $\mathrm{C}$ & 2 & $\mathrm{H}$ & 1 & 76 & 8.06 & 10.42 & 7 & 41 & 16.03 & 18.39 & Tie & MS & $\begin{array}{l}\text { verified by } \\
\text { XRF }\end{array}$ & $\begin{array}{l}\text { Shipboard - } \\
\text { verified }\end{array}$ & \\
\hline U1488 & B & 3 & $\mathrm{H}$ & 3 & 71 & 14.11 & 18.39 & 5 & 58 & 16.98 & 21.26 & Tie & MS & $\begin{array}{l}\text { verified by } \\
\text { XRF }\end{array}$ & $\begin{array}{l}\text { Shipboard - } \\
\text { verified }\end{array}$ & \\
\hline U1488 & C & 3 & $\mathrm{H}$ & 1 & 109 & 17.89 & 21.26 & 7 & 10 & 25.9 & 29.27 & Tie & $\mathrm{XRF}$ & & Revised & B-2 to $C-3$ tie revised \\
\hline U1488 & $\mathrm{B}$ & 4 & $\mathrm{H}$ & 3 & 124 & 24.14 & 29.27 & 5 & 77 & 26.67 & 31.8 & Tie & MS & $\begin{array}{l}\text { verified by } \\
\text { XRF }\end{array}$ & $\begin{array}{l}\text { Shipboard - } \\
\text { adjusted }\end{array}$ & $\begin{array}{l}\text { Top and bottom B-4 interval and } \\
\text { CSF adjusted by } 1 \mathrm{~cm}\end{array}$ \\
\hline U1488 & $C$ & 4 & $\mathrm{H}$ & 1 & 81 & 27.11 & 31.8 & 7 & 25 & 35.42 & 40.11 & Tie & MS & $\begin{array}{l}\text { verified by } \\
\text { XRF }\end{array}$ & $\begin{array}{l}\text { Shipboard - } \\
\text { adjusted }\end{array}$ & $\begin{array}{l}\text { Top and bottom C- } 4 \text { interval and } \\
\text { CSF adjusted by } 1 \mathrm{~cm}\end{array}$ \\
\hline U1488 & $\mathrm{B}$ & 5 & $\mathrm{H}$ & 4 & 23 & 34.13 & 40.11 & 5 & 31 & 35.71 & 41.69 & Tie & MS & $\begin{array}{l}\text { verified by } \\
\quad \text { XRF }\end{array}$ & $\begin{array}{l}\text { Shipboard - } \\
\text { verified }\end{array}$ & \\
\hline U1488 & $C$ & 5 & $\mathrm{H}$ & 1 & 57 & 36.37 & 41.69 & 7 & 8 & 44.88 & 50.2 & Tie & MS & $\begin{array}{l}\text { verified by } \\
\quad \mathrm{XRF}\end{array}$ & $\begin{array}{l}\text { Shipboard - } \\
\text { adjusted }\end{array}$ & $\begin{array}{l}\text { Top C-5 interval and CSF adjusted } \\
\text { by } 1 \mathrm{~cm}\end{array}$ \\
\hline U1488 & B & 6 & $\mathrm{H}$ & 4 & 91 & 44.31 & 50.2 & 5 & 135 & 46.25 & 52.14 & Tie & MS & $\begin{array}{l}\text { verified by } \\
\text { XRF }\end{array}$ & $\begin{array}{l}\text { Shipboard - } \\
\text { adjusted }\end{array}$ & $\begin{array}{l}\text { Top B- } 6 \text { interval and CSF adjusted } \\
\text { by } 1 \mathrm{~cm}\end{array}$ \\
\hline U1488 & $C$ & 6 & $\mathrm{H}$ & 1 & 83 & 46.13 & 52.14 & 6 & 150 & 54.3 & 60.31 & Tie & PWL & $\begin{array}{l}\text { MS; } \\
\text { verified } \\
\text { by XRF }\end{array}$ & $\begin{array}{l}\text { Shipboard - } \\
\text { verified }\end{array}$ & \\
\hline U1488 & B & 7 & $\mathrm{H}$ & 4 & 67 & 53.57 & 60.31 & 6 & 61 & 56.51 & 63.25 & Tie & MS & $\begin{array}{l}\text { verified by } \\
\text { XRF }\end{array}$ & $\begin{array}{l}\text { Shipboard - } \\
\text { verified }\end{array}$ & \\
\hline U1488 & $\mathrm{C}$ & 7 & $\mathrm{H}$ & 2 & 82 & 57.12 & 63.25 & 7 & 11 & 63.91 & 70.04 & Tie & MS & $\begin{array}{l}\text { verified by } \\
\text { XRF }\end{array}$ & $\begin{array}{l}\text { Shipboard - } \\
\text { verified }\end{array}$ & \\
\hline U1488 & $\mathrm{B}$ & 8 & $\mathrm{H}$ & 3 & 83 & 61.67 & 70.04 & 5 & 144 & 65.28 & 73.65 & Tie & $\mathrm{XRF}$ & & Revised & $\begin{array}{l}\text { C-7 to B-8 tie revised; Bottom B-8 } \\
\text { interval and CSF adjusted by } 1 \mathrm{~cm}\end{array}$ \\
\hline U1488 & $C$ & 8 & $\mathrm{H}$ & 2 & 31 & 66.11 & 73.65 & 6 & 121 & 73.01 & 80.55 & Tie & MS & $\begin{array}{l}\text { verified by } \\
\text { XRF }\end{array}$ & $\begin{array}{l}\text { Shipboard - } \\
\text { adjusted }\end{array}$ & $\begin{array}{l}\text { Bottom C- } 8 \text { interval and CSF } \\
\text { adjusted by } 1 \mathrm{~cm}\end{array}$ \\
\hline U1488 & B & 9 & $\mathrm{H}$ & 4 & 42 & 72.32 & 80.55 & 5 & 144 & 74.84 & 83.07 & Tie & MS & $\begin{array}{l}\text { verified by } \\
\text { XRF }\end{array}$ & $\begin{array}{l}\text { Shipboard - } \\
\text { adjusted }\end{array}$ & $\begin{array}{l}\text { Top B-9 interval and CSF adjusted } \\
\text { by } 1 \mathrm{~cm}\end{array}$ \\
\hline U1488 & $C$ & 9 & $\mathrm{H}$ & 1 & 93 & 74.73 & 83.07 & 7 & 15 & 82.95 & 91.29 & Tie & $\mathrm{XRF}$ & & Revised & $\begin{array}{l}\text { B-9 to C-9 and C-9 to B-10 ties } \\
\text { revised }\end{array}$ \\
\hline U1488 & B & 10 & $\mathrm{H}$ & 4 & 82 & 82.22 & 91.29 & 6 & 65 & 85.05 & 94.12 & Tie & XRF & & Revised & $\begin{array}{l}\mathrm{C}-9 \text { to } \mathrm{B}-10 \text { and } \mathrm{B}-10 \text { to } \mathrm{C}-10 \text { ties } \\
\text { revised }\end{array}$ \\
\hline U1488 & $C$ & 10 & $\mathrm{H}$ & 1 & 129 & 84.59 & 94.12 & 6 & 112 & 91.92 & 101.45 & Tie & XRF & & Revised & $\begin{array}{l}\text { B-10 to } C-10 \text { and } C-10 \text { to } B-11 \text { ties } \\
\text { revised }\end{array}$ \\
\hline U1488 & B & 11 & $\mathrm{H}$ & 4 & 89 & 91.79 & 101.45 & 6 & 122 & 95.12 & 104.78 & Tie & XRF & & Revised & $\mathrm{C}-10$ to $\mathrm{B}-11$ tie revised \\
\hline U1488 & C & 11 & $\mathrm{H}$ & 2 & 37 & 94.67 & 104.78 & 6 & 34 & 100.64 & 110.75 & Tie & MS & $\begin{array}{l}\text { verified by } \\
\quad \text { XRF }\end{array}$ & $\begin{array}{l}\text { Shipboard - } \\
\text { adjusted }\end{array}$ & $\begin{array}{l}\text { Bottom C- } 11 \text { interval and CSF } \\
\text { adjusted by } 1 \mathrm{~cm}\end{array}$ \\
\hline U1488 & B & 12 & $\mathrm{H}$ & 4 & 36 & 100.76 & 110.75 & 6 & 58 & 103.48 & 113.47 & Tie & MS & $\begin{array}{c}\text { GRA,PWL; } \\
\text { verified } \\
\text { by XRF }\end{array}$ & $\begin{array}{l}\text { Shipboard - } \\
\text { verified }\end{array}$ & \\
\hline U1488 & C & 12 & $\mathrm{H}$ & 1 & 41 & 102.71 & 113.47 & 6 & 99 & 110.79 & 121.55 & Tie & $\mathrm{XRF}$ & & Revised & B-12 to $C-12$ tie revised \\
\hline U1488 & B & 13 & $\mathrm{H}$ & 4 & 140 & 111.3 & 121.55 & 6 & 30 & 113.2 & 123.45 & Tie & GRA & $\begin{array}{l}\text { PWL; } \\
\text { verified } \\
\text { by XRF }\end{array}$ & $\begin{array}{l}\text { Shipboard - } \\
\text { verified }\end{array}$ & \\
\hline U1488 & C & 13 & $\mathrm{H}$ & 1 & 64 & 112.44 & 123.45 & 6 & 11 & 119.41 & 130.42 & Tie & $\mathrm{XRF}$ & & Revised & B-13 to $\mathrm{C}-13$ tie revised \\
\hline U1488 & B & 14 & $\mathrm{H}$ & 4 & 48 & 119.88 & 130.42 & 6 & 119 & 123.59 & 134.13 & Tie & $\mathrm{XRF}$ & & Revised & $\begin{array}{l}\text { Removed A-14 from splice; New tie } \\
\text { from B-14 to C-14 }\end{array}$ \\
\hline U1488 & C & 14 & $\mathrm{H}$ & 1 & 69 & 121.99 & 134.13 & 6 & 95 & 129.75 & 141.89 & Tie & XRF & & Revised & $\begin{array}{l}\text { Removed A-14 from splice; New tie } \\
\text { from B-14 to C-14 }\end{array}$ \\
\hline U1488 & B & 15 & $\mathrm{H}$ & 4 & 130 & 130.2 & 141.89 & 6 & 82 & 132.72 & 144.41 & Tie & GRA & $\begin{array}{l}\text { GRA; } \\
\text { verified } \\
\text { by XRF }\end{array}$ & $\begin{array}{l}\text { Shipboard - } \\
\text { verified }\end{array}$ & \\
\hline U1488 & C & 15 & $\mathrm{H}$ & 1 & 108 & 131.88 & 144.41 & 6 & 126 & 139.56 & 152.09 & Tie & GRA & $\begin{array}{l}\text { PWL; } \\
\text { verified } \\
\text { by XRF }\end{array}$ & $\begin{array}{l}\text { Shipboard - } \\
\text { adjusted }\end{array}$ & $\begin{array}{l}\text { Bottom C-15 interval and CSF } \\
\text { adjusted by } 1 \mathrm{~cm}\end{array}$ \\
\hline U1488 & B & 16 & $\mathrm{H}$ & 4 & 108 & 139.48 & 152.09 & 6 & 12 & 141.52 & 154.13 & Tie & PWL & $\begin{array}{l}\text { verified by } \\
\text { XRF }\end{array}$ & $\begin{array}{l}\text { Shipboard - } \\
\text { adjusted }\end{array}$ & $\begin{array}{l}\text { Top B-16 interval and CSF adjusted } \\
\text { by } 1 \mathrm{~cm}\end{array}$ \\
\hline U1488 & C & 16 & $\mathrm{H}$ & 1 & 76 & 141.06 & 154.13 & 7 & 9 & 149.39 & 162.46 & Tie & $\mathrm{XRF}$ & & Revised & B- 16 to $C-16$ tie revised \\
\hline U1488 & B & 17 & $\mathrm{H}$ & 4 & 121 & 149.11 & 162.46 & 7 & 7 & 152.28 & 165.63 & Tie & PWL & $\begin{array}{l}\text { verified by } \\
\text { XRF }\end{array}$ & $\begin{array}{l}\text { Shipboard - } \\
\text { adjusted }\end{array}$ & $\begin{array}{l}\text { Bottom B-17 interval and CSF } \\
\text { adjusted by } 1 \mathrm{~cm}\end{array}$ \\
\hline
\end{tabular}


Table T2 (continued). (Continued on next page.)

\begin{tabular}{|c|c|c|c|c|c|c|c|c|c|c|c|c|c|c|c|c|}
\hline \multirow[b]{2}{*}{ Site } & \multirow[b]{2}{*}{ Hole } & \multirow[b]{2}{*}{ Core } & \multirow[b]{2}{*}{$\begin{array}{l}\text { Core } \\
\text { type }\end{array}$} & \multicolumn{4}{|c|}{ Top of revised splice interval } & \multicolumn{4}{|c|}{$\begin{array}{l}\text { Bottom of revised splice } \\
\text { interval }\end{array}$} & \multirow[b]{2}{*}{$\begin{array}{l}\text { Splice } \\
\text { type }\end{array}$} & \multirow[b]{2}{*}{$\begin{array}{l}\text { Data used } \\
\text { for tie point }\end{array}$} & \multirow[b]{2}{*}{$\begin{array}{l}\text { Other data } \\
\text { needed to } \\
\text { verify tie }\end{array}$} & \multirow[b]{2}{*}{ Status } & \multirow[b]{2}{*}{ Comment } \\
\hline & & & & Section & $\begin{array}{l}\text { Offset } \\
(\mathrm{cm})\end{array}$ & $\begin{array}{l}\text { Depth } \\
\text { (mbsf) }\end{array}$ & $\begin{array}{l}\text { Depth } \\
\text { CCSF } \\
(\mathrm{m})\end{array}$ & Section & $\begin{array}{l}\text { Offset } \\
(\mathrm{cm})\end{array}$ & $\begin{array}{l}\text { Depth } \\
\text { (mbsf) }\end{array}$ & $\begin{array}{l}\text { Depth } \\
\text { CCSF } \\
\text { (m) }\end{array}$ & & & & & \\
\hline U1488 & A & 17 & $\mathrm{H}$ & 3 & 60 & 152 & 165.63 & 4 & 107 & 153.97 & 167.6 & Tie & PWL & $\begin{array}{l}\text { verified by } \\
\text { XRF }\end{array}$ & $\begin{array}{l}\text { Shipboard - } \\
\text { verified }\end{array}$ & \\
\hline U1488 & B & 18 & $\mathrm{H}$ & 1 & 73 & 153.63 & 167.6 & 7 & 9 & 161.99 & 175.96 & Tie & $\mathrm{XRF}$ & & Revised & A-17 to B-18 tie revised \\
\hline U1488 & $A$ & 18 & $\mathrm{H}$ & 3 & 116 & 162.06 & 175.96 & 5 & 27 & 164.17 & 178.07 & Tie & PWL & $\begin{array}{l}\text { NGR; } \\
\text { verified } \\
\text { by XRF }\end{array}$ & $\begin{array}{l}\text { Shipboard - } \\
\text { verified }\end{array}$ & \\
\hline U1488 & B & 19 & $\mathrm{H}$ & 1 & 104 & 163.44 & 178.07 & 7 & 9 & 171.49 & 186.12 & Tie & PWL & $\begin{array}{l}\text { NGR; } \\
\text { verified } \\
\text { by XRF }\end{array}$ & $\begin{array}{l}\text { Shipboard - } \\
\text { adjusted }\end{array}$ & $\begin{array}{l}\text { Top B-19 interval and CSF adjusted } \\
\text { by } 1 \mathrm{~cm}\end{array}$ \\
\hline U1488 & A & 19 & $\mathrm{H}$ & 3 & 104 & 171.44 & 186.12 & 4 & 135 & 173.25 & 187.93 & Tie & PWL & $\begin{array}{l}\text { NGR; } \\
\text { verified } \\
\text { by XRF }\end{array}$ & $\begin{array}{l}\text { Shipboard - } \\
\text { verified }\end{array}$ & \\
\hline U1488 & B & 20 & $\mathrm{H}$ & 1 & 50 & 172.4 & 187.93 & 7 & 29 & 181.19 & 196.72 & Tie & PWL & $\begin{array}{l}\text { NGR; } \\
\text { verified } \\
\text { by XRF }\end{array}$ & $\begin{array}{l}\text { Shipboard - } \\
\text { verified }\end{array}$ & \\
\hline U1488 & $A$ & 20 & $\mathrm{H}$ & 3 & 146 & 181.36 & 196.72 & 5 & 38 & 183.28 & 198.64 & Tie & GRA & $\begin{array}{l}\text { PWL,NGR; } \\
\text { verified } \\
\text { by XRF }\end{array}$ & $\begin{array}{l}\text { Shipboard - } \\
\text { verified }\end{array}$ & \\
\hline U1488 & B & 21 & $\mathrm{H}$ & 1 & 92 & 182.32 & 198.64 & 7 & 24 & 190.64 & 206.96 & Tie & XRF & & Revised & $\begin{array}{l}\mathrm{A}-20 \text { to } \mathrm{B}-21 \text { and } \mathrm{B}-21 \text { to } \mathrm{A}-21 \text { ties } \\
\text { revised }\end{array}$ \\
\hline U1488 & $A$ & 21 & $\mathrm{H}$ & 3 & 141 & 190.81 & 206.96 & 4 & 116 & 192.06 & 208.21 & Tie & $\mathrm{XRF}$ & & Revised & B-21 to $A-21$ tie revised \\
\hline U1488 & B & 22 & $\mathrm{H}$ & 1 & 55 & 191.45 & 208.21 & 6 & 119 & 199.59 & 216.35 & Tie & GRA & $\begin{array}{l}\text { verified by } \\
\quad \text { XRF }\end{array}$ & $\begin{array}{l}\text { Shipboard - } \\
\text { adjusted }\end{array}$ & $\begin{array}{l}\text { Top B-22 interval and CSF adjusted } \\
\text { by } 1 \mathrm{~cm}\end{array}$ \\
\hline U1488 & $A$ & 22 & $\mathrm{H}$ & 3 & 106 & 199.96 & 216.35 & 5 & 80 & 202.7 & 219.09 & Tie & GRA & $\begin{array}{l}\text { verified by } \\
\text { XRF }\end{array}$ & $\begin{array}{l}\text { Shipboard - } \\
\text { verified }\end{array}$ & \\
\hline U1488 & B & 23 & $\mathrm{H}$ & 1 & 114 & 201.54 & 219.09 & 7 & 29 & 209.69 & 227.24 & Tie & $\mathrm{XRF}$ & & Revised & $\begin{array}{l}\text { A- } 22 \text { to } B-23 \text { and } B-23 \text { to } A-23 \text { tie } \\
\text { revised }\end{array}$ \\
\hline U1488 & $A$ & 23 & $\mathrm{H}$ & 4 & 24 & 210.14 & 227.24 & 5 & 95 & 212.35 & 229.45 & Tie & $\mathrm{XRF}$ & & Revised & B-23 to A-23 tie revised \\
\hline U1488 & B & 24 & $\mathrm{H}$ & 1 & 103 & 210.93 & 229.45 & 6 & 133 & 218.73 & 237.25 & Tie & PWL & $\begin{array}{l}\text { NGR; } \\
\text { verified } \\
\text { by XRF }\end{array}$ & $\begin{array}{l}\text { Shipboard - } \\
\text { verified }\end{array}$ & \\
\hline U1488 & $A$ & 24 & $\mathrm{H}$ & 4 & 12 & 219.52 & 237.25 & 5 & 75 & 221.65 & 239.38 & Tie & GRA & $\begin{array}{l}\text { NGR; } \\
\text { verified } \\
\text { by XRF }\end{array}$ & $\begin{array}{l}\text { Shipboard - } \\
\text { verified }\end{array}$ & \\
\hline U1488 & B & 25 & $\mathrm{H}$ & 1 & 78 & 220.18 & 239.38 & 6 & 84 & 227.74 & 246.94 & Tie & PWL & $\begin{array}{l}\text { NGR,GRA; } \\
\text { verified } \\
\text { by XRF }\end{array}$ & $\begin{array}{l}\text { Shipboard - } \\
\text { adjusted }\end{array}$ & $\begin{array}{l}\text { Top B-25 interval and CSF adjusted } \\
\text { by } 1 \mathrm{~cm}\end{array}$ \\
\hline U1488 & A & 25 & $\mathrm{H}$ & 3 & 110 & 228.5 & 246.94 & 5 & 14 & 230.54 & 248.98 & Tie & PWL & $\begin{array}{l}\text { NGR,GRA; } \\
\text { verified } \\
\text { by XRF }\end{array}$ & $\begin{array}{l}\text { Shipboard - } \\
\text { adjusted }\end{array}$ & $\begin{array}{l}\text { Top A-25 interval and CSF adjusted } \\
\text { by } 1 \mathrm{~cm}\end{array}$ \\
\hline U1488 & B & 26 & $\mathrm{H}$ & 1 & 68 & 229.58 & 248.98 & 6 & 148 & 237.88 & 257.28 & Tie & $L^{*}$ & $\begin{array}{l}\text { GRA; } \\
\text { verified } \\
\text { by XRF }\end{array}$ & $\begin{array}{l}\text { Shipboard - } \\
\text { verified }\end{array}$ & \\
\hline U1488 & A & 26 & $\mathrm{H}$ & 4 & 20 & 238.6 & 257.28 & 6 & 14 & 241.54 & 260.22 & Tie & $\mathrm{XRF}$ & & Revised & $\begin{array}{l}\mathrm{B}-26 \text { to } \mathrm{A}-26 \text { and } \mathrm{A}-26 \text { to } \mathrm{B}-27 \text { ties } \\
\text { revised }\end{array}$ \\
\hline U1488 & B & 27 & $\mathrm{H}$ & 2 & 40 & 240.3 & 260.22 & 5 & 43 & 244.83 & 264.75 & Tie & $\mathrm{XRF}$ & & Revised & A-26 to B-27 tie revised \\
\hline U1488 & A & 27 & $\mathrm{H}$ & 2 & 38 & 245.28 & 264.75 & 6 & 89 & 251.79 & 271.26 & Tie & GRA & $\begin{array}{l}\text { verified by } \\
\text { XRF }\end{array}$ & $\begin{array}{l}\text { Shipboard - } \\
\text { verified }\end{array}$ & \\
\hline U1488 & B & 28 & $\mathrm{H}$ & 2 & 83 & 250.23 & 271.26 & 4 & 115 & 253.55 & 274.58 & Tie & XRF & & Revised & A-27 to $B-28$ tie revised \\
\hline U1488 & $A$ & 28 & $\mathrm{H}$ & 1 & 127 & 254.17 & 274.58 & 5 & 28 & 259.18 & 279.59 & Tie & GRA & $\begin{array}{l}\mathrm{L}^{*}, \mathrm{PWL}, \mathrm{N} \\
\mathrm{GR} \\
\text { verified } \\
\text { by } \mathrm{XRF}\end{array}$ & $\begin{array}{l}\text { Shipboard - } \\
\text { adjusted }\end{array}$ & $\begin{array}{l}\text { Top and bottom A-28 interval and } \\
\text { CSF adjusted by } 1 \mathrm{~cm}\end{array}$ \\
\hline U1488 & B & 29 & $\mathrm{H}$ & 1 & 80 & 258.2 & 279.59 & 5 & 1 & 263.41 & 284.8 & Tie & GRA & $\begin{array}{l}\mathrm{L}^{*}, \mathrm{PWL}, \mathrm{N} \\
\mathrm{GR} \\
\text { verified } \\
\text { by XRF }\end{array}$ & $\begin{array}{l}\text { Shipboard - } \\
\text { adjusted }\end{array}$ & $\begin{array}{l}\text { Bottom B-29 interval and CSF } \\
\text { adjusted by } 1 \mathrm{~cm}\end{array}$ \\
\hline U1488 & $A$ & 29 & $\mathrm{H}$ & 1 & 143 & 263.83 & 284.8 & 6 & 82 & 270.7 & 291.67 & Tie & GRA & $\begin{array}{l}\mathrm{L}^{*}, \mathrm{PWL}, \mathrm{N} \\
\text { GR; } \\
\text { verified } \\
\text { by XRF }\end{array}$ & $\begin{array}{l}\text { Shipboard - } \\
\text { verified }\end{array}$ & \\
\hline U1488 & B & 30 & $\mathrm{H}$ & 2 & 115 & 269.55 & 291.67 & 4 & 97 & 272.37 & 294.49 & Tie & XRF & & Revised & $\begin{array}{l}\text { A-29 to B-30 tie revised; Bottom B- } \\
30 \text { interval and CSF adjusted by } 1 \\
\mathrm{~cm}\end{array}$ \\
\hline U1488 & $A$ & 30 & $\mathrm{H}$ & 1 & 93 & 272.83 & 294.49 & 5 & 17 & 278.07 & 299.73 & Tie & GRA & $\begin{array}{l}\mathrm{L}^{*}, \mathrm{PWL} ; \\
\text { verified } \\
\text { by } \mathrm{XRF}\end{array}$ & $\begin{array}{l}\text { Shipboard - } \\
\text { verified }\end{array}$ & \\
\hline U1488 & B & 31 & $\mathrm{H}$ & 1 & 85 & 277.25 & 299.73 & 4 & 138 & 282.28 & 304.76 & Tie & GRA & $\begin{array}{l}\text { MS; } \\
\text { verified } \\
\text { by XRF }\end{array}$ & Revised & $\begin{array}{l}A-30 \text { to } B-31 \text { and } B-31 \text { to } A-31 \text { ties } \\
\text { revised }\end{array}$ \\
\hline U1488 & $A$ & 31 & $\mathrm{H}$ & 1 & 111 & 282.51 & 304.76 & 6 & 128 & 290.18 & 312.43 & Tie & XRF & & Revised & B-31 to A-31 tie revised \\
\hline
\end{tabular}


Table T2 (continued).

\begin{tabular}{|c|c|c|c|c|c|c|c|c|c|c|c|c|c|c|c|c|}
\hline \multirow[b]{2}{*}{ Site } & \multirow[b]{2}{*}{ Hole } & \multirow[b]{2}{*}{ Core } & \multirow[b]{2}{*}{$\begin{array}{l}\text { Core } \\
\text { type }\end{array}$} & \multicolumn{4}{|c|}{ Top of revised splice interval } & \multicolumn{4}{|c|}{$\begin{array}{l}\text { Bottom of revised splice } \\
\text { interval }\end{array}$} & \multirow[b]{2}{*}{$\begin{array}{l}\text { Splice } \\
\text { type }\end{array}$} & \multirow[b]{2}{*}{$\begin{array}{l}\text { Data used } \\
\text { for tie point }\end{array}$} & \multirow[b]{2}{*}{$\begin{array}{l}\text { Other data } \\
\text { needed to } \\
\text { verify tie }\end{array}$} & \multirow[b]{2}{*}{ Status } & \multirow[b]{2}{*}{ Comment } \\
\hline & & & & Section & $\begin{array}{l}\text { Offset } \\
(\mathrm{cm})\end{array}$ & $\begin{array}{l}\text { Depth } \\
\text { (mbsf) }\end{array}$ & $\begin{array}{l}\text { Depth } \\
\text { CCSF } \\
(\mathrm{m})\end{array}$ & Section & $\begin{array}{l}\text { Offset } \\
(\mathrm{cm})\end{array}$ & $\begin{array}{l}\text { Depth } \\
\text { (mbsf) }\end{array}$ & $\begin{array}{l}\text { Depth } \\
\text { CCSF } \\
\text { (m) }\end{array}$ & & & & & \\
\hline U1488 & B & 32 & $\mathrm{H}$ & 3 & 10 & 289 & 312.43 & 4 & 137 & 291.77 & 315.2 & Tie & GRA & $\begin{array}{l}\text { MS; } \\
\text { verified } \\
\text { by XRF }\end{array}$ & $\begin{array}{l}\text { Shipboard - } \\
\text { adjusted }\end{array}$ & $\begin{array}{l}\text { Bottom B-32 interval and CSF } \\
\text { adjusted by } 1 \mathrm{~cm}\end{array}$ \\
\hline U1488 & A & 32 & $\mathrm{H}$ & 1 & 86 & 291.76 & 315.2 & 6 & 136 & 299.76 & 323.2 & Tie & $\mathrm{XRF}$ & & Revised & $\begin{array}{l}\text { A-32 to B-33 tie revised: ambiguous } \\
\text { tie, difficult to align even with XRF }\end{array}$ \\
\hline U1488 & B & 33 & $\mathrm{H}$ & 3 & 56 & 298.96 & 323.2 & 7 & 69 & 305.09 & 329.33 & Tie & XRF & & Revised & $\begin{array}{l}\text { A-32 to B-33 tie revised: ambiguous } \\
\text { tie, difficult to align even with XRF }\end{array}$ \\
\hline U1488 & $A$ & 34 & $\mathrm{~F}$ & 1 & 1 & 305.11 & 329.89 & 4 & 56 & 309.76 & 334.54 & Append & XRF & & Revised & Appended $30 \mathrm{~cm}$ lower \\
\hline U1488 & $A$ & 35 & $\mathrm{~F}$ & 1 & 1 & 309.81 & 334.98 & 4 & 52 & 314.52 & 339.69 & Append & $\mathrm{XRF}$ & & Revised & Appended $30 \mathrm{~cm}$ lower \\
\hline
\end{tabular}

